National University "Odessa Academy of Law"

\title{
CRIME, CRIMINAL LEGISLATION AND RESPONSIBILITY: \\ GENERAL PROVISIONS OF CRIMINAL CODE OF UKRAINE, 2001
}

Training manual 


\section{UDC 343(477)(072) \\ C 89}

Recommended for publishing by the Decision of EducationMethodical Council of the National University "Odesa Academy of Law" Protocol \# 1 of 25 September, 2017

\section{Reviewers:}

N.V. Petlyuchenko, Doctor of Philology, Professor, Head of Foreign Languages Department \# 2 of the National University "Odesa Academy of Law"

O.v. Kozachenko, Dr. of Laws, Professor, Head of Criminal Law and Other Criminal Related Disciplines Department of the Mykolayiv Law Institute of the National University "Odesa Academy of Law"

English vesion of this training manual was reviewed by Head of Foreign Languages Department \#1 at National University "Odesa Academy of Law”, Candidate of Phil. Science, Associate Professor Julia V. Yulinetzka.

Crime, Criminal Legislation and Responsibility: General C 89 provisions of Criminal Code of Ukraine, 2001 - a training manual - 2nd Edition. - Vyacheslav A. Tulyakov, Eugene L. Streltsov, Eugene Y. Polyansky, Elena N. Polishchuk. - Riga, Latvia: Izdevnieciba "Baltija Publishing", 2017. - 104 p. - (Series: Study guides).

This textbook (manual) deals with up to date and debatable issues in the sphere of criminal liability. It includes generalized overview of crime issue, corpus delicti ant its elements, peculiarities of qualification and criminal liability individualization. Based on the provisions of Ukrainian criminal law and relevant aspects of common law countries criminal laws and judicial practice, and taking into consideration provisions of the European countries criminal laws and the European Court of Human Rights practice, this textbook reveals in a more detailed form the characteristics of corpus delicti, its elements and features, and their role in differentiating of criminal and non-criminal behavior. Special emphasis is given to issues of criminal policy, criminalization and the role of criminal legislation in combating crime, including aspects of harmonization with the ECHR practice. Contemporary status and perspectives of Ukrainian criminal policy further development are also analyzed herein.

This textbook (manual) may be useful for all those interested in national and foreign criminal law issues and is fluent in English. 


\section{Удк 343(477)(072) \\ K 82}

Рекомендовано до друку Навчамьно-методичною радою Національного університету "Одеська юридична академія" (протоком № 1 від 25.09.2017 р.)

\section{Рецензенти:}

Н. В. Петмюченко, доктор філологічних наук, професор, завідувач кафедри іноземних мов № 2 Національного університету "Одеська юридична академія"

О. В. Козаченко, доктор юридичних наук, професор, завідувач кафедри кримінального права та інших кримінально-правових дисциплін Миколаївського інституту права Національного університету "Одеська юридична академія"

\section{Кримінальне право, кримінальне законодавство та К 82 відповідамьність: загальні положення Кримінального кодексу України, 2001 : навч. посіб. / В. О. Туляков,

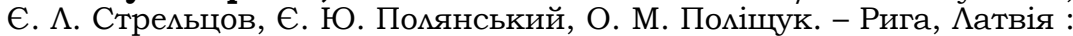 Видавництво "Baltija Publishing", 2017. - 104 с. - (Серія: Навчальні посібники).}

\footnotetext{
У навчально-методичному посібнику висвітлені актуальні та дискусійні питання у сфері кримінальної відповідальності. Посібник містить узагальнений огляд питань змочину, складу змочину та його емементів, особливостей кваліфікації та індивідуалізації кримінальної відповідальності. На підставі аналізу норм кримінального законодавства України та релевантних аспектів кримінального законодавства та судової практики країн загальної системи права, а також 3 урахуванням положень європейського кримінального законодавства та практики Європейського суду з прав мюдини деталізована характеристика елементів та ознак складу змочину та їх ролі при розмежуванні змочинної та незмочинної поведінки. Приділена увага дослідженню питань кримінальної політики, криміналізації та ролі кримінального законодавства в сфері боротьби зі змочинністю, в тому числі і в аспекті гармонізації 3 практикою ЄСП Проаналізовані питання, пов'язані 3 сучасним станом та перспективами удосконалення української кримінальної політики.

Посібник може бути корисним усім тим, хто цікавиться питаннями національного та іноземного кримінального права та володіє англійською мовою.
}

(C) В. О. Туляков, 2017

(C) Є. А. Стрельцов, 2017

(c) Є. Ю. Полянський, 2017

(C) О. М. Поліщук, 2017 


\section{CONTENTS}

PRINCIPAL NOTES PROGRAM 6

1. INTRODUCTION OBJECTIVES OF CRIMINAL POLICY........ 6

2. CONTEMPORARY CRIMINAL POLICY OF UKRAINE........... 11

3. CRIMINALIZATION - GENERAL PRINCIPLES OF LAWMAKING. APPROACHES TO DEFINING THE CATEGORY OF CRIME

4. THE CONCEPT OF CRIME. GENERAL PRINCIPLES OF CRIMINAL LAW.

5. CORPUS DELICTI. THE BASICS

OF CRIMINAL LIABILITY 36

6. ACTUS REUS - GENERAL CHARACTERISTICS OF OFFENSIVE CONDUCT 40

7. PERSONALITY OF A CRIMINAL AS CRITERIA OF CRIMINAL LIABILITY INDIVIDUALIZATION 51

8. MENS REA - POSITIVE AND NEGATIVE FAULT REQUIREMENTS 60

PLANS OF PRACTICAL TRAINING 71 USED SOURCES 102 


\section{Course Objectives}

1. To understand key legal terms (notion, definition, analysis and understanding), clauses, and chronologies in criminal law

2. To understand the criminal elements of crimes

3. To examine the historical evolution of criminal law maxims, doctrines, and principles

4. To analyze both early and contemporary judicial thinking and legal reasoning

5. To articulate informed opinion over important, controversial issues in criminal law

\section{General Education Goals}

The more general goals of this course are to provide the student with the following tools to help develop his or her potential:

1. Development of the student's analytical thinking capabilities through comparison and contrast in the application of theories and concepts to social problems Enhancement of the student's literacy skills through assigned readings, discussions, examinations, and other requirements

2. Utilization of the historical perspective which helps with student understanding of evolutionary developments over time

3. Understanding of the scientific method through research requirements and in-depth case studies

4. Improvement in social interaction skills and understanding human behavior through consideration of the impact legal and social systems have on individuals Increased student awareness of cultural and multi-cultural issues through study of how social problems and social movements are related to, and affect, minority groups

5. Preparation for more advanced study in criminal justice

Essentially, students will be required to demonstrate that they recognise the central legal issues involved in the questions set, and that they can apply the appropriate principles as set out in the relevant statutes.

Authors appreciate very much the given possibility to spread classical methods and information on Principles of Criminal Law and Criminal Justice due to Dr. Thomas O'Connor's Web Syllabus on Criminal Law, Joshua Dressler's Black Letter Outline on Criminal Law, Encyclopedia of Crime and Justice and Andrew Ashworth's Principles of Criminal Law that were used while composing this course. 


\section{PRINCIPAL NOTES PROGRAM}

\section{INTRODUCTION OBJECTIVES OF CRIMINAL POLICY}

Criminal lawyers of nowadays while trying to conceptualize the essence of criminal justice in contemporary world argued whether the modern system of criminal justice is suitable to administer justice, i.e. not only appropriate to improve the protection of human rights, but also to promote justice and peace in general (Anne Kindt). Merchandising criminal practices, hate crimes, corruption and organized criminal activity actually have no borders and limits. Marginalization of immigrants does not contradict the widespread misuse of law on international and national level but lead to criminal behaviors worldwide. Deviance and misuse of law became the features of modern way of life, of society's existence. The same we could say to crime phenomena.

Development of public law worldwide is substantially stipulated be lingering state of global economic crisis. Legal system of Ukraine is not an excluding from this general rule, taking in account existing risks for budgetary sphere created by shadow economy, corruption etc. All of manifestations, created by global economic crisis, to certain extents, produce reflections at the scopes of legal systems. It engraves existing global challenges, stipulated by transnational organized crime, ethnonational and religious terrorism and others.

Such challenges do require appropriate responses in the sphere of public law, particularly - criminal law. To give a global response - is a task of the European Community. But the burden "local" reactions to existing situation is assigned at law enforcement bodies of states, and even in greater extent - is within the scope of their legislation bodies.

On 22 January 2014 the World Economic Forum was opened in Davos. Traditionally, several days before its opening a group of experts (over 700 people) publishes a special report on the prognostic characteristics of the main risks which may essentially influence the world economic, political and social development. 
The report ${ }^{1}$ of 2014 , based on the data of social statistics, expert and mass opinion polls in the last 10 years, has distinguished 31 kinds of main risks, which are global by their nature and have a substantial potential due to the chances of causing negative consequences for the development of not just certain industries but entire countries. Among others, they include economic, natural, geopolitical, social and technological risks. The most significant ones are:

1. The financial crisis in the economics of the world's leading countries

2. The high level of unemployment

3. The lack of water resources

4. The disproportion in income distribution among population

5. The failure of the policy of adaptation to the climate change

6. A high probability of negative weather cataclysms.

7. The failure of the policy of global governance

8. The food crisis

9. The failure of the system of main financial mechanisms and institutes

10. The high level of political and social instability.

Some of the highlighted factors may be divided into systemic groups; a number of them is and will be making substantial impact on the European criminal policy.

The first group includes factors connected with the instability in the rapidly growing worldwide multipolarity. This concerns not only the global economic imbalances, the criminality of which hasn't been studied enough. It is known that the changes in social, political and cultural ties and processes lead not only to positive results but also to the rise of poverty and social oppression, marginalization, i.e. processes of a high criminal menace. Along with that, the diversification of ties and economic possibilities opens a way for the growth of criminal practices, the formation of new potentials for the development of organized criminal activity.

Though a year ago we used to pay attention to the problems of illicit traffic in narcotic drugs, weapons, trade in human beings, nowadays attention is attracted to the world market of adulterate medicines created by organized crime, pirate trade of manufactured goods and foods, abuse in paper issue and

1 World Economic Forum Global Risks 2014 report. [electronic resource] // Geneva, Ninth edition, 2014 - [mode of access http://www3.weforum.org/ docs/WEF_GlobalRisks_Report_2014.pdf 
circulation and in the process of brokerage, dealer and management activity. The criminal practices that have been shaped in the mentioned spheres have obvious signs of the organized ones ${ }^{2}$.

At the same time, regionalization of crime is an important tendency, as the changing social and demographic conditions in the world and the growth of national middle class, regional authorities and interests lead to minimization of the system of multinational global government and its influence on the regional economies. It may lead to the weakening of legal regulators on international, supranational and supernational levels, and, as a result, to replacement of these positions by criminally oriented structures in the spheres of public health (trade in adulterate medicines), financial services (fake financial brokerage, fraudulent financial practices), energy sector (cartel deals). Such a changeable business landscape will naturally cause successive growth of corruption in state structures. Globalization has provided the environment for a growing internationalization of criminal activities. Multinational criminal syndicates have significantly broadened the range of their operations from drug and arms trafficking to money laundering. Typically, strengthening the capacity of governments to reform legislation and criminal justice systems; establishing institutions and mechanisms for the detection, investigation, prosecution and adjudication of various types of crimes; upgrading the skills of criminal justice personnel are the basic elements in modern criminal policy worldwide (see Stanford Law School notions).

The implementation of the provisions of Lisbon Treaty in the sphere of securing the stability, safety and rule of law zone and the global protection of human rights in European countries have been sequentially leading to the necessity of unification of legislation on ordinary crimes and offences. This is what the modern action plans of the parliaments and legal committees of different countries of Europe operating in the framework of implementation of Stockholm Protocol 2009 are aimed at.

That is why European Commission has asked member states to criminalize market abuse in forms of Insider dealing and

\footnotetext{
2 Rogelio Madrueño Aguilar. Global imbalances and the dark side of progress. The effect of modern irruption of violence on the economic growth in Latin America Santander, 2012 - [mode of access http://congresoreedes.unican.es/actas/ PDFs/41.pdf]; see also: http://www.flarenetwork.org/Report/ dictionary/ globalisation_and_crime.htm
} 
Market manipulation. Naturally it depends on the state - how to criminalize it or make it an administrative offence. The emphasis on the publicity of criminalization criteria reduces the quality of legal guarantees of the right to privacy under Art. 6 of the Convention, taking into account the sovereignty of the construction and implementation of criminal policy concepts of each separate country.

As a result, the expansion of the limits of formalization of criminal prohibitions in the practice of the ECHR requires the gradual development in the sphere of subsequent formalization of characteristics of privacy protection level, strengthening legal guarantees of rights and freedoms of citizens.

The resolution of the issue: harmonization of national legislation, the development of universal mechanisms of control over new kinds of criminal practices, unification of sanctions and the system of criminal legal response in the system of interstate formations on ordinary crimes and crimes with higher expectancy of being organized.

Another risk group is the criminality of the "lost" generation. Those who came of age in 2010's face high unemployment level and impossibility to find a use of themselves and their resources on national as well as global scale. It is known that in Ukraine, notwithstanding the relatively low level of unemployment among the youth, only $36 \%$ of employers work in their own field, and $44 \%$ had to change their profession ${ }^{3}$. Those who are not able to find a job at all stand a chance of becoming criminals. Sociologists are working with the new group of youngsters: young people known as NEETs - not in employment, education or training. A huge number of people, having graduated prestigious and high-paid institutes of higher education, are obliged to change their profession due to the absence of vacancies of labor market.

Such a social dissatisfaction in the whole world servers as a nutrient medium for the forming of groupings of extremist orientation, terrorists and ordinary offenders.

In this relation, along with the acts of misuse of law becoming more frequent, the law nihilism, the breach of traditional ties and relations, a high level of frustration of this social group, a

\footnotetext{
${ }^{3}$ http:/ / sostav.ua/publication/ne-po-spetsialnosti-rabotaet-bolshe-polovinyukraintsev-59254.html
} 
concept of gradual rise of the cases of kidnapping attracts more attention.

And this is not the case of the "daring 90's" getting back. This is a general tendency that can be seen in all regions of the planet among the new "digital" generation stuck in communications and fast ways of enrichment. Kidnapping may have several aims, from simple lucre to revenge to the powerful ones, urge for selfexpression, or financing organized crime (right up to the terrorist groupings). Along with that, in a number of cases this act is considered by national legislatures as a crime of average gravity (for instance, p.2 of Article 146 of the Criminal Code of Ukraine, providing criminal liability for illegal confinement or abduction of a person committed in regard of a minor, or for mercenary purposes, or in regard of two or more persons, or by a group of persons upon their prior conspiracy, or by a method dangerous to the victim's life or health, or causing bodily suffering to him or her, or with the use of weapons, which, according to Article 12 of the Criminal Code, is to be considered a crime of average gravity). It appears that in modern conditions, the disposition of this norm should be substantially changed and the sanctions of the articles on illegal confinement should be diversified.

The third group of risks lies in digital disintegration. Nowadays in the world of cyber communications, attacking is easier than guarding oneself. The systems of defense against invasion of secrecy of private life and correspondence do not exist. States and individuals, corporations and social groups enter the Internet with the purpose of capturing and collection of personal data and communications as well as organizing illicit business. Thereupon, the system of protection of the unified cyberspace needs to have a global nature. Resolving the issues on supranational level is no longer enough here. The menace is so high that it requires the development of the UN Minimum Standard Rules on prevention of crimes in cyberspace and treatment of cyber offenders. 


\section{CONTEMPORARY CRIMINAL POLICY OF UKRAINE}

The implementation of the provisions of Lisbon Treaty in the sphere of securing the stability, safety and rule of law zone and the global protection of human rights in European countries has been sequentially leading to the necessity of unification of legislation on ordinary crimes and offences. This is what the modern action plans of the parliaments and legal committees of different countries of Europe operating in the framework of implementation of Stockholm Protocol 2009 are aimed at. This is what the activities of Ukrainian parliamentarians are aimed at as well. The approximation of Ukrainian legislation to the European norms and standards has also touched the sphere of criminal regulation.

It is a common knowledge that the new Criminal Procedure Code 2012 passed by the Parliament of Ukraine has established the extended approach to construction of criminal offense approved in most European countries, embracing both a crime and a criminal misdemeanor. Being a purely procedural category in the context of the mentioned law, the phenomenon of a criminal misdemeanor has given rise to quite a big controversy in the environment of substantial law experts.

First, the current criminal legislation of Ukraine doesn't stipulate the division of criminal offenses into crimes and misdemeanors.

Second, the extended construction entails uncertainties in the law enforcement practice, increases the dark figure of crime, and fundamentally shifts the notions of structure and dynamics of deviance and methods of its analysis.

Third, assigning gravity of an act based on type sanctions imposed for its commitment as a classification criterion doesn't fully correspond with the realia, taking into account the amendments made to article 12 of the Criminal Code of Ukraine in the course of humanization of the current legislation.

To address these deficiencies and to form new concept, of the President of Ukraine with his Decree № 98/2012-rp has formed a working group on the issues of reforming the legislation on administrative offenses and introduction of criminal misdemeanors in Ukraine. The theoretical model of the concept 
of criminal misdemeanors is also developed at the Department of Criminal Law of the National University "Odessa Law Academy"4.

The traditionalist Criminal Code of France 1810 contained a three-merous classification of criminal acts (violations of the criminal law), distinguishing "criminal misdemeanors" and "criminal offenses" along with the actual crime. Punishability of the act served as the criterion of distinction for the legislator. Hereat, as L. Golovko rightly pointed out, criminal offenses were minor criminal infractions punishable only with "police penalties", primarily a fine, the cases on which were considered by the so-called "police courts"; criminal misdemeanors were more serious violations of the criminal law punishable with socalled "corrective punishment" including more stringent penalties up to imprisonment for several years, cases of which were considered by the so-called "corrective courts" consisting of a number of professional judges; and crimes - the most dangerous criminal infractions, punishable with called "criminal penalties"5. With changes in the regulation of misconduct taking administrative measures in Eastern Europe and the dyadic division of criminal offenses in its central part, this model in one way or another effectively manifests itself in combating crime.

Therewith, deviant behavior has become a norm for the biggest part of the population. What is at issue is criminal practices hiding in borderline dark figure, what is at issue is everyday crime having become mass due to their subjective "everydayness", not even speaking about palled systematic acts of corruption.

Meanwhile, the increase of criminal offences is on the rise, being dependant on the level of anomie in the society and the norm awareness of the citizens. And following this, we accumulate the experience of naming and punishing them respectively. Now the members of the Presidential Commission are making an attempt to unify non-managerial administrative delicts, disciplinary offenses, and some civil offenses into a single category of a criminal offense. A tendency of over-criminalization emerges and is clearly seen as the methods criminal law are

\footnotetext{
${ }^{4}$ Dmytruk M.M. "The Category of Misdemeanors in the Criminal Law Doctrine", diss. ... cand. jur. sciences - 12.00.08 - Odessa, 2012. - 228 p.

5 Golovko L.V. The Analysis of the Project Concept of the Criminal Code of Kazakhstan Republic. [electronic source] - Access mode http:/ / www.zakon.kz/4480131-analiz-koncepcii-proekta-ugolovnogo.html
} 
considered to be one of the basic and essential ones for use in the country when controlling deviations.

However, the subjectively explained selectivity of choice of acts caused by the procedural and administrative unprovability of specific infringements will lead to social injustice, when the poor are sent to jail, while the powers that be buy off. In the view of introduction of the new Criminal Procedure Code we will face a situation where after enactment of a criminal law provision the professionals will have to wait for months for clarifications regarding the peculiarities of classification of an act and enforcement of a norm to offenders. This will really lead to systematic violations of human rights, to the formation of social groups stigmatized as potential criminals, deformation of stereotypes and ideals of law and justice.

Hence, first, over-criminalization leads to "desiccation" of preventive and punitive function of criminal prohibition.

And second, amorphism of criminal norm is a precondition of mass violations of human rights and controllable judicial discretion.

From our point of view, the main criterion for the criminalization of acts is defined in Part 2 of Article 11 of the Criminal Code of Ukraine (an act of inflicting significant damage to an individual person or legal entity, society, state).

The paradox of modern public law doctrine is the gradual smearing of publicity, the return of presuming of primacy of the individual, the private over the state, the public, the social. It can be clearly traced in the criminal works. The task of criminal law in utilitarian, legalistic sense is the protection of constitutional norms and principles. As a matter of fact, a Criminal Code is a Constitution with sanctions. Incompleteness of the process of constitutional reform and instability of regulation of relations will lead to inefficiency and palliative nature of criminal law recodification novels, the formation of a new set of temporary "dead" norms.

Criminal regulation should be not so much a tool to protect the state from encroachments on its sovereignty and security as an instrument of protection of the rights and freedoms of an individual and a community.

The emphasis on the community justice, the justice of the involved is particularly important when reorienting the vector of criminal law protection, not upon words but upon deeds. 
One may lingeringly talk about the "smearing" of the object of criminal regulation until the state policy not in words but in reality turns its attention to the victims of a crime and the approval of humanistic social values as a priority of criminal protection. We have already had an occasion to write that recodification is not possible without the change of the idea.

This means that there's a need for a new Theoretical Model of the Criminal Code of Ukraine designed for the stable development of relations of nation-building and utmost protection of the rights and legitimate interests of individuals.

Thus, it was suggested that the constitutional conditioning of penal prohibition, the connectivity to the norms of the Constitution of the state and the internationally recognized principles and fundamental freedoms of a human and a citizen be present in the preamble to the future Criminal Law. Among the participants of criminal relations (an offender - the state - a victim - a third person) a central place should be occupied by a victim.

Only penalty should serve as the essence and the substance of liability, while the restoration of rights of the victim should be assigned to other mandatory measures of response to a criminal act.

The legal support of protecting the rights and freedoms of a crime victim should become the main purpose of the new Criminal Code. In this regard, any Criminal Code is built with justification of prohibition of infringements against a person, property, society and state, as well as against a range of moral values declared as the basic ones for the society and supported by it.

Other acts should be decriminalized, passed over to the category of criminal misdemeanors, or instituted on the claim of victims (including the state and other social entities).

At the same time, the extension of the system of private prosecution should lead to the expansion of alternative ways of responding to a crime.

This involves describing the issues related to the imposition of not only punishment, but also other measures of criminal law (security, social protection, restitution, compensation) to the offender in the General Part of the Criminal Code. Here it is necessary to append a description of "ne bis dem idem" principle with a reference to the fact that serving a sentence does not relieve from a responsibility of an offender to a victim. 
The consistent formalization of the doctrine of a crime and a criminal misdemeanor with the new classification and taxonomy based on the concept of criminal law in the broad sense is mandatory. There are known court rulings of the European Court of Human Rights (for instance, the Ozturk v. Germany case - the Judgement of 21 February 1984, the Gurepka v. Ukraine case the Judgement of 6 September 2005), which prescribe that any "administrative offenses" remain a part of criminal matter (matière pénale) in the broad sense. Accordingly, in the Putz v. Austria Judgment of 22 February 1996, as most criminologists believe, the ECHR on the basis of interpretation of the European Convention on Human Rights and Fundamental Freedoms has developed the doctrine of "criminal matters", which covers criminal law, criminal procedure and a part of administrative relations, particularly relations associated with the use of administrative penalties. The assignment of a certain relation to "criminal matters" is made, in the opinion of L.Golovko, considering both formal (the position of the national lawmaker) and substantial criteria (nature of an offense and severity of a sanction imposed).

Thus, the criteria for the classification of offenses in national law, the characteristics of the legal nature of offenses having regard to the prevalence of the legal treatment of the nature of an anti-social act in the States parties of the Convention, the nature and character of gravity of penalties and other sanctions applied are, according to the practice of application of Article 6 by the ECHR, the grounds for attributing certain acts to criminal offenses, regardless of how and in what way these acts are classified by the national legislation.

Naturally, the emphasis on the publicity of these criteria reduces the quality of legal guarantees of the right to privacy under Art. 6 of the Convention, taking into account the sovereignty of the construction and implementation of criminal policy concepts of each separate country.

As a result, the expansion of the limits of formalization of criminal prohibitions in the practice of the ECHR requires the gradual development in the sphere of subsequent formalization of characteristics of privacy protection level, strengthening legal guarantees of rights and freedoms of citizens.

Hence, when forming of the concept of criminal offenses and distinguishing the category of misdemeanors that comply with 
the European standards and requirements of harmonization of national legislation, it is necessary:

- to carry out systematic analysis of offenses and acts referable to the criminal ones;

- to clearly indicate the significance of harm to personal and public interest, state sovereignty for criminalization in national law (the social contract in supranational criminal law) and sequential decriminalization and depenalization of all the other acts based on the criminal matter principle;

- to allocate the institute of a victim in the system of the General Part, to form the norm establishing that criminal misdemeanors are acts cases on which are instituted only upon a victim's claim.

The issue of the protection of relations in the area of the acts decriminalized in future, in our view, should be resolved in terms of forming the mechanisms of public-social justice and in the sphere of private regulation. In this context, there's a need for the structural improvement of the doctrine of criminal law in terms of a clearer description of the forms and types of criminal pressure, principles, sources, jurisdictional powers, the grounds of liability, the peculiarities of non-institution and discharge of criminal liability, approximation rules, criminal law thesaurus.

This cycle of works includes addressing a range of problems of doctrinal nature, from multi-track criminal pressure to the utmost formalization of the grounds non-institution to liability (immunities and privileges in criminal law) and toughening the liability of habitual criminals in order to protect the public interest ${ }^{6}$.

${ }^{6}$ Section 225 of the UK Criminal Justice Act 2003; ECHR Chamber judgment in the case of James, Wells and Lee v. the United Kingdom (ECHR 340 (2012) 18.09.2012 


\section{CRIMINALIZATION - GENERAL PRINCIPLES OF LAWMAKING. APPROACHES TO DEFINING THE CATEGORY OF CRIME}

It is all too easy to take the criminal law for granted, as an essential or ineliminable aspect of our social lives. Even those who do take the criminal law for granted, however, face a range of questions about its proper role and scope. The obvious question is that of criminalization: what kinds of consideration or principle should guide legislative decisions about what to criminalize? The Harm Principle ${ }^{7}$, long seen by liberals both as a protection against an over-expansive and over-moralised criminal law and as a positive guide to the criminal law's proper concerns, has come under attack: its central problem is that of providing an account of 'harm' that will equip the principle to set substantive and plausible limits on the scope of the criminal law. But what other principles or values should guide decisions about criminalization?

Is a crime simply a prohibition that appears in one of the state or federal penal codes under the heading "criminal"? Or is the criminal category a deeper one, one that does not derive its meaning from any particular use to which the notion of crime is put? The first would be what we might call a "positivistic" stance toward the notion of an offense. It treats crime entirely as a legislative concept. The second would be a normative stance toward the notion of an offense identifying the criminal category by a theory of justified prohibition. On a positive approach, there can be no objection to punishing corporations or enhancing the role of the victim, since there is no obligatory content to the notion of an offense. On a normative approach, by contrast, there may be grounds for objecting to these modifications to the traditional treatment of crime. For it may turn out that punishing an offender at the behest of the victim, especially if associated with the payment of restitution, is not legitimate according to our best theory of justified punishment.

The positivistic approach. Henry Hart jestingly reflected the essence of the positivistic approach, saying that "a crime is

\footnotetext{
7 Michael Green Mill's Harm Principle // Social and Political Philosophy - 33 2010 - [electronic version] - Mode of access: http://carneades.pomona.edu/ 2010-SPP/nts-0329.shtml
} 
anything which is called a crime, and a criminal penalty is simply the penalty provided for doing anything which has been given that name" . The prevailing approach of the American legal system toward crime is positivistic. By refusing to recognize constitutional boundaries on the notion of an offense, this is precisely the position the U.S. Supreme Court has articulated over the course of the last fifty or so years. The Court has held, for example, that a legislature may criminalize conduct without including a mental state element (mens rea) in the definition of the offense (U.S. v. Dotterweich; U.S. v. Balint). It has also found it a matter of legislative discretion whether to treat exonerating conditions like insanity as part of the definition of the offense to which they apply or as so-called affirmative defenses. The former approach would place the burden on the prosecution to prove, for example, that the defendant was not insane at the time he performed the criminal act, whereas the latter would place the burden on the defendant to prove he was. The Court famously articulated its commitment to the positivistic approach to crime in a case involving the defense of extreme emotional disturbance where it upheld a New York provision that shifted the burden to the defendant to prove the defense, instead of requiring the prosecution to prove the absence of the defense beyond a reasonable doubt (Patterson $v$. New York). Given its premise, the Court's reasoning was flawless: It argued that because a state has the power to eliminate the defense altogether, it must also have the power to shift the burden to the defendant to prove it, since "the greater power implies the lesser power".

The same argument has been found applicable to other defenses as well, even one as fundamental as self-defense. Recently, however, the Supreme Court has indicated a renewed willingness to place limits on state burden-shifting. The case concerned a New Jersey hate-crime statute that authorized substantially increased penalties for any defendant whose crime was committed from the motive of racial animus. The Court found the statute unconstitutional on the grounds that it obviated the state's duty to prove mental state by treating racial bias as a sentencing factor instead of as an element of the offense. The implication of such a decision is that legislatures do not have unfettered discretion to decide how and whether to

\footnotetext{
${ }^{8}$ Henry M. Hart Jr., The Aims of the Criminal Law, 23 Law and ContemporaryProblems 401-441 (Summer 1958) [electronic version] - Mode of access: https://scholarship.law.duke.edu/lcp/vol23/iss3/2
} 
criminalize, even outside the area of fundamental rights. For if it is constitutionally impermissible for a state to shift the burden on a mental state element, it would seem to follow that it does not have unfettered discretion to decide whether to include such mental state elements in its offense definitions in the first instance. The question, then, is whether the Court's recent holding in the area of burden of proof signals a fundamental shift away from the positivist approach to crime, or whether its influence will be confined to the area of burden of proof. Is the Court embarking on a new constitutional jurisprudence of substantive criminal law or will it continue to shy away from any real attempt to place limits on the substantive criminal provisions legislatures can pass?

While the positivistic approach to crime has prevailed, there are some isolated areas in which the Supreme Court has traditionally attempted to place limitations on offense definition. For the most part, these limitations have consisted of a set of formal restrictions on how legislatures may draft offenses, stemming from the due process clauses of the Fifth and Fourteenth Amendments. While these restrictions purport to speak only to how conduct is criminalized, rather than what is criminalized, they often turn out to impose substantive conditions on offense definition as well. Consider, for example, the following four important limitations on the notion of an offense. First, the doctrine of vagueness requires that criminal statutes define the prohibited conduct with sufficient specificity to place potential defendants on notice of their vulnerability to criminal prosecution. This doctrine has most notably been applied to loitering ordinances, many of which are thought to leave too much discretion to police officers to arrest individuals on grounds of physical appearance or demeanor. In many cases, the objection to such statutes would not be eliminated by more precise drafting. As the Court made clear in a recent case involving a Chicago loitering ordinance, sometimes a statute cuts too deeply into the ordinary activities of everyday life, with too little justification, to be constitutionally acceptable (City of Chicago $v$. Morales).

A second, related doctrine is that of overbreadth, which forbids a legislature from drafting criminal statutes in a way that risks prosecution and conviction for ordinary, noncriminal behavior. The Court will strike down criminal statutes on overbreadth grounds mostly where the prohibition risks infringing freedom of 
speech and expression (R.A.V. v. City of St. Paul). A third doctrine is also articulated under the heading of "due process," namely the doctrine of legality. Criminal statutes must provide clear notice of a citizen's potential subjection to criminal punishment in order to afford ordinary citizens a fair opportunity to conform their behavior to the law. For example, punishment must not be retroactive, and it must be certain and definite. Finally, the Eighth Amendment ban on "cruel and unusual punishment" has been interpreted as containing a doctrine of proportionality that serves to restrict the punishment selected for a given offense (Solem v. Helm; see Harmelin v. Michigan). While this doctrine retains its force mostly in the death penalty area, it has served in the past to ensure that the sanction authorized for a given offense is roughly on a part with the sanction for the same offense in other jurisdictions, and that it is appropriate given the sanction authorized for other offenses in the same jurisdiction ${ }^{9}$.

Nonpositivist approaches. The foregoing limitations on the notion of an offense suggest that while the positivistic approach to offense definition may be the prevailing one in our constitutional jurisprudence, there is reason to question the depth of our commitment to it. We do not in fact accept that any conduct a legislature wishes to make criminal is rightly punished, and the restrictions we impose on the use of the criminal sanction cannot be entirely accounted for as restrictions imposed by the first eight amendments to the Constitution.

Some conduct seems so unsuitable as an object of criminal prohibition that we feel it stretches the concept of crime to apply it to those cases. In extreme cases the point would be clear: Statutes that made criminal punishment retroactive rather than prospective, that punished for thoughts without any accompanying deeds, that enacted a separate set of prohibitions for each separate member of the community, that established a separate count of theft for each thirty-second period that a thief withheld the stolen item from its owner, or that adopted an arbitrary class of subjects to whom the prohibition would apply, would be so out of keeping with the way we think of crime that we might be inclined to reject the suggestion that the statutes made the conduct (or thoughts) crimes. In what sense would they be crimes? Simply arresting a person and subjecting him to

\footnotetext{
${ }^{9}$ Crime: Definition - The Positivistic Approach // http://law.jrank.org/ pages / 777 / Crime-Definition-positivistic-approach.html
} 
incarceration or other harsh treatment does not by itself make the conduct for which he was arrested criminal. It does not even do so when the legislature has authorized the behavior in the form of a law. While one might hope to limit the use of the criminal sanction in such cases by the sorts of ancillary constitutional restrictions on legislative discretion discussed above, these will prove insufficient to capture our current understanding of crime. It may be, therefore, that it is the concept of crime itself that limits what a legislature may prohibit and how it may ensure adherence to those limits.

At least to some extent, then, our understanding of crime is normative as well as descriptive. In particular, there may be conditions of justification that are themselves part of the notion of crime. If this is correct, then part of what we mean when we speak of a criminal offense is that the infringement of liberty the statute authorizes is justified by the importance of inducing conformity with the criminal prohibition. This approach would suggest not only that punishing an individual for something he had no reason to know was forbidden is not, properly speaking, punishment, but that the conduct thus penalized could not be correctly called "criminal," even if the legislature has called it a crime and has attached the kinds of penalties to it that typically accompany so-called criminal conduct. The normative approach to crime would thus provide a way of evaluating legislative uses of the power to criminalize by establishing criteria that are internal to the notion of crime itself. Such criteria would make it possible to say quite directly that the legislature erred in prohibiting a certain kind of conduct and providing stringent penalties for its occurrence, on the grounds that the prohibited conduct is not an appropriate object of criminal prohibition. And while legislatures might have significant latitude in determining the acceptable objects of criminal prohibition, under a normative approach to crime, their decision-making would operate within certain broadly defined limits ${ }^{10}$.

Legal moralism. Unlike their judicial counterparts, criminal law scholars tend to favor some sort of normative approach to the notion of an offense. There is, however, no nonpositivistic definition of crime that would command uniform assent among them. One school of thought about crime is called "legal

10 Claire Finkelstein. Encyclopedia of Crime and Justice // http://www.encyclopedia.com/law/legal-and-political-magazines/crime-definition 
moralism." The legal moralist maintains that a crime is an immoral act, and accordingly that all and only immoral acts ought to be punished. Thus the legal moralist not only believes that every crime is in some way an immoral act, or that it tends to produce an immoral act, but also that there are no immoral acts that should go unpunished. One class of crime appears to pose a problem for the legal moralist, namely the crimes often referred to as mala prohibita. Mala prohibita crimes identify acts that are bad only because the legislature has forbidden them. By contrast, mala in se crimes prohibit acts that are bad in and of themselves. The legal moralist has difficulty with this distinction, because he seems to regard all crimes as mala in se, to the extent that he thinks it is the underlying immorality of an act that justifies prohibiting it under the criminal law. Legal moralists sometimes seek to solve the problem of mala prohibita crimes by saying that the acts they prohibit are instrumentally related to an act or state of affairs that is mala in se. While it is not immoral to drive on the left rather than on the right, it is immoral to impose grave risk of injury on one's fellows. In this way, the legal moralist explains the law mandating driving on the left, in the United States, or on the right, in Britain, as a necessary prohibition in order to avoid the truly immoral act of plowing into cars coming in the opposite direction ${ }^{11}$.

Social practice view. A second nonpositivistic view of the notion of an offense sees crimes as prohibited acts, where the explanation for these prohibitions is that they are forbidden by certain social practices, or by those possessing authority to make criminalization decisions in light of a social practice allocating the power to do so. H. L. A. Hart, for example, thought of criminal law as a set of "primary rules" designed to regulate conduct. But the primary rules, he argued, are law only because they are made by officials whose authority rests on a social practice that identify $s$ when a rule counts as law. The rule that men must remove their hats in church, he wrote, identifies a social practice. But not all social practices have the force of law. Unlike customs and ordinary, quotidian conventions, the social rules that are law are ones that are identified in a special way within the practice as having the force of law. Only those rules possessing a certain "pedigree," namely those created by

${ }^{11}$ Claire Finkelstein. Encyclopedia of Crime and Justice // http://www.encyclopedia.com/law/legal-and-political-magazines/crime-definition 
individuals authorized by "secondary rules" to create, interpret, and apply primary rules, will be so recognized. The social practice view of crime may seem similar to the positivistic approach, given that both approaches treat crime as a set of prohibitions created by those authorized to do so. It might thus be thought simply a different brand of positivism. But unlike the US Supreme Court's brand of positivism about crime, Hart's account would allow for evaluative judgments about a legislature's criminalization decisions, based on their fidelity to an underlying notion of crime. A legislature that created draconian criminal prohibitions under a social practice view could be found to be exceeding its authority as established by the relevant secondary rules. As such, its dictates would not have the force of law ${ }^{12}$.

Economic account. A third prominent nonpositivistic alternative is the economic account of crime. According to some theorists, a crime is an inefficient act-inefficient because it bypasses a voluntary market. Criminal sanctions are necessary to give individuals sufficient incentive to obtain what they want through the market, rather than to take what they want by force. In this, criminal sanctions are slightly different from civil penalties. While the legal economist sees rules of civil and criminal liability as serving the same purpose, namely to provide incentives for efficient behavior, the incentive structures needed to promote efficiency for the two kinds of acts diverge. According to the economic account of crime, the criminal sanction ought to apply to acts that are always inefficient. The criminal law must threaten potential defendants with sufficiently stringent punishment to ensure that criminal acts are never worthwhile. Sometimes, by contrast, the acts that violate civil law are in fact efficient, despite the fact that they are prohibited. It is thus sometimes efficient to allow individuals to break a contract or to run a risk of injuring another person. Unlike criminal sanctions, which must always induce conformity, the penalty for civil wrongs need only be equal to the damage caused in order to provide the incentives for efficient behavior. By forcing injurers or those wishing to breach a contract to "internalize" the cost of the damage they cause, they will injure or breach only when it is efficient to do so. Criminal penalties are just like civil penalties, 12 Claire Finkelstein. Encyclopedia of Crime and Justice //
http://www.encyclopedia.com/law/legal-and-political-magazines/crime-definition 
with the exception that civil sanctions must contain a "kicker" added to the damage caused, in order to ensure that it is never sufficiently advantageous to violate the prohibitory norm. Indeed, the decreasing distance between tort law and criminal law in recent years may itself be testimony to the influence of law and economics on judicial and legislative methodology. While the positivistic view of crime enjoys a rhetorical advantage in our system, the actual understanding of crime our legal system presupposes seems rather to display an admixture of descriptive and normative facts. We look to legislative pronouncement to learn the content of those prohibitions we call "crimes," but we also make normative judgments about criminal statutes based on an implicit sense of what constitutes a correct application of the notion of crime. It is perhaps, moreover, because the conceptual limits of "crime" are reasonably well ensconced in our public use of the term that states do not attempt to eliminate the defense of self-defense or, for the most part, make chatting on a street corner a crime ${ }^{13}$.

Harm-based theory. Jeremy Bentham is often thought of as the father of legal positivism. But even Bentham recognized that the notion of crime must incorporate normative elements. Bentham took the standard positivist line that laws, and criminal laws in particular, are commands of the sovereign. Whatever is commanded has the force of law. But Bentham also argued interestingly that a command does not count as law if it is not "complete." In order for a law to be complete, it has to identify a discrete harm or evil at which the legal prohibition aims. Thus even for Bentham, the notion of crime rests on a pre-legislative concept, namely the notion of harm. Building an account of crime on the idea of harm represents a fourth nonpositivistic approach. The beginnings of such an account were suggested by John Stuart Mill, who articulated what has come to be known as the "harm principle." In On Liberty Mill wrote: "The only purpose for which power can rightfully be exercised over any member of a civilized community against his will is to prevent harm to others".

More recently, Joel Feinberg ${ }^{14}$ has developed Mill's basic approach in greater detail. He has argued, however, that harm may not provide the only legitimate grounds for making criminal

\footnotetext{
13 Claire Finkelstein. Encyclopedia of Crime and Justice // http://www.encyclopedia.com/law/legal-and-political-magazines/crime-definition 14 Joel Feinberg, The Moral Limits of the Criminal Law: Harmless Wrongdoing. New York: Oxford University Press. - 1988. - P. 319.
} 
sanction. Even if Feinberg is right that we do not adhere to the harm principle without exception, the harm principle may nevertheless lie at the heart of American criminal law's approach to the notion of an offense ${ }^{15}$.

All societies conduct on-going debates to inform their policy making. In this particular debate, there has been some uncertainty as to the nature and extent of the contribution to be made by the victims of crime. All governments collect some statistics as to the incidence of crime within their territory, and accept a general role in offering some degree of protection to their citizens as an aspect of the social contract. The Positivist School asked, why did this person offend? The Neo-Classical School and Left Idealism - from opposite political perspectives - asked why this social reaction was made to this behavior? And conventional victimology asked, why is this type of person victimized? Tulyakov (2000) and others argue that victimology has become politicised, and that biased exploitation of research materials is both driving the cycle of criminalisation and decriminalisation, and distorting the criminal justice system. The concern is that, a focus on the victim promotes rights selectively for certain victims, and advocates the assumption that some victim rights are more important than competing rights or values in society.

In theory, society reaches a consensus view on whether certain acts or behaviour are harmful. In cases where there is agreement, the criminal justice system may be extended to treat those matters as crimes. Conversely, when society has evidence that it is no longer at risk from such acts or behavior, they may be decriminalized. For example, Recommendation No. R (95) 12 adopted by the Committee of Ministers of the Council of Europe on the management of criminal justice, advocates that crime policies such as decriminalization, depenalisation or diversion, and mediation should be adopted wherever possible. But the law and order debate between right and left politicians is often superficial and unscientific, formulating policies based on their appeal to an uniformed electorate rather than properly conducted research. Encouraged by the politicians, the media which is increasingly owned by large corporations, endorses each new war on crime and drugs, ignoring all the others that have been fought and lost before. Its bias toward official and corporate perspectives 15 Claire Finkelstein. Encyclopedia of Crime and Justice //
http://www.encyclopedia.com/law/legal-and-political-magazines/crime-definition 
on criminal justice are so strong that some regard crime news as essentially propaganda ${ }^{16}$.

Leading criminal law philosophers, such as Dennis Baker ${ }^{17}$ and Joel Feinberg have argued that conduct should only be criminalized when it is fair to do so. In particular, such theorists assert that objective reasons are needed to demonstrate that it is fair to criminalize conduct in any given case. The commonly cited objective justification for invoking the criminal law is harm to others, but it cannot deal with all situations. For example, people are not necessarily harmed by public nudity. Offence to others also provides an objective reason for invoking the criminal law, but it clearly does not as offence is determined according to conventional morality ${ }^{18}$.

People experience a range of physical and social injuries in different contexts which will vary according to the level of economic and political development of their country. When a state debates whether to respond to a source of injury by criminalising the behavior that produces it, there are no pre-set criteria to apply in formulating social policy. There is no ontological reality to crime. The criminal justice system responds to a substantial number of events that do not produce significant hardship to individual citizens. Moreover, events which do cause serious injuries and perhaps should be dealt with as crimes, e.g. situations of corporate manslaughter, are either ignored or dealt with as civil matters.

The criminalisation process defines and classifies behaviour. It broadcasts the laws so that no-one may have the excuse of ignorance, and disposes of those who will not obey. There are now more criminal laws and they are penetrating deeper into the social structures of modern societies ${ }^{19}$. Crime control has become an industry, yet it remains ineffective in providing protection to all its citizens from harm. Such as it is, the process is made up of three components:

\footnotetext{
${ }^{16}$ Has victimology outlived its usefulness? // http://www.academia.edu/ 30979376/Has_victimology_outlived_its_usefulness

17 Dennis J. Baker, The Right Not to be Criminalized: Demarcating Criminal Law's Authority, (London: Ashgate Applied Legal Philosophy Series, 2011 - 308 p.

Dennis J. Baker, Glanville Williams: Textbook of Criminal Law, (London: 3rd edn., Sweet \& Maxwell, 2012 - 1504 p.

18 Law and Morality // http://www.academia.edu/14992558/LAW_AND_ MORALITY

19 Individuality and Criminality: Conflict Driving Elements // https: / / books.google.com.ua/books?id=KgI3CgAAQBAJ\&pg=PT51\&lpg=PT51\&dq
} 
Creation of a social order. ${ }^{20}$ This is both a socio-economic process, thus, society must develop the apparatus of law creation, law enforcement and punishment and the system must be acceptable to the majority of those who live in the community. If the laws do not match the general mores, their enforcement will be a source of friction and disharmony. Conformity to the social order must, for the most part, be self-enforced.

For the times when self-enforcement fails, society must create a legal order. This part of the process sees the centralization of power within the institutions of the political state. Some states justified the criminalization process as demonstrating their concerns about safety and security, the policy of control, policing, criminal justice, and penal practice. The modern state is decentralizing and privatizing its functions. This is changing the character and content of the remaining institutions of the state which must now work co-operatively with other for-profit agencies $^{21}$.

Ontological basis of crime. Put in the most simple terms, ontology deals with or establishes the clear grounds for being. In some of the traditional schools ontology proper is deemed beyond the scope of legal thought, in accord with the modern distinction between society and state (which some consider based in the distinction the Romans made between themselves and their Italian allies, the socii, but not given the theoretical articulation we recognize today. One need consider no further than the claim that man is a political animal to see this is so. As a political animal, man has come to see himself as possessed of rights (UN Human Rights Council, http://www.ohchr.org/english/ bodies/hrcouncil/) - whether these are the universal human rights advocated vigorously toward establishment today through the matrix of commercialism. Thus, again in simple terms, and to the extent that human beings are indeed political beings, crime does seem to have an ontological basis. The point is that one may, with some justice, argue persuasively that being is divided. This need not, however, force the question of meta-political crimes. However, the question of criminalisation is not one question, but many. Criminal law can be contrasted with a range of other kinds of legal regulation or provision: for instance:

20 Douglas North, John Walls, Barry Weingast. Creation of New Social Order Cambridge Univ Press - 2009

21 Criminalization // https://en.wikipedia.org/wiki/Criminalization 
Many kinds of harmful or wrongful conduct constitute both criminal and civil wrongs, whilst in other cases the matter is seen as one for the criminal rather than the civil law, or for the civil law rather than the criminal law ${ }^{22}$.

Some legal systems distinguish crimes properly speaking from 'administrative violations'; other modes of administrative regulation involve rules and penalties, but do not count and are not seen as part of the system of criminal law; English lawyers talk of a category of 'quasi-criminal', 'regulatory' offences that are formally part of the criminal law but do not involve 'real' crimes.

A by now familiar argument from advocates of 'restorative justice', and from other penal abolitionists, is that we should move away from a criminal law response to many of the kinds of conduct that are defined and treated as crimes, and look instead to more informal modes of mediation and conflict resolution.

In each of these contexts, we must ask what could justify a criminal law approach: why should we treat certain kinds of conduct as 'crimes', rather than as civil wrongs, or as administrative violations, or as conflicts that need to be resolved?

To tackle these questions, we need to work towards a clearer account of the possible, proper aims of a system of criminal law, and of the role that the criminal law can properly play in a liberal democracy.

The Moral Limits of the Criminal Law that addresses the question, What acts may the state rightly make criminal? Feinberg identifies four liberty-limiting, or coercion-legitimizing, principles, each of which is the subject of a volume of his book. In the first volume, Feinberg looks at the principle of harm to others - or the harm principle.

The other principles that Feinberg considers in subsequent volumes are

(1) the offense principle: it is necessary to prevent hurt or offense (as opposed to harm) to others;

(2) legal paternalism: it is necessary to prevent harm to the actor herself; and

(3) legal moralism: it is necessary to prevent immoral conduct whether or not it harms anyone ${ }^{23}$.

Criminalisation on the EU level. The EU has been taking measures in the area of criminal law for more than a decade,

${ }^{22}$ Criminalization // https://en.wikipedia.org/wiki/Criminalization

23 Joel Feinberg The Moral Limits of Criminal Law. Offence to others (1988) // https://www.amazon.co.uk/Moral-Limits-Criminal-Law-Offense/dp/0195052153 
with the goal of better fighting crime which has become increasingly international and sophisticated. In 2005, the Court of Justice of the European Union ruled, in a watershed decision, that the European Parliament and the Council did have the power to adopt criminal law sanctions where it is essential in order to facilitate the enforcement of EU law. The Lisbon Treaty (notably Articles 83 and 325 of the Treaty on the Functioning of the European Union) enables the EU to adopt - under certain conditions - minimum rules on criminal law concerning the definitions of criminal offences and the sanctions, if EU rules are not effectively enforced. The Lisbon Treaty has also changed the legal framework for EU criminal law measures: no criminal law measure can be decided without the agreement of the European Parliament and the Court of Justice of the European Union now has full judicial control. The new Treaty also strengthens the role of national Parliaments substantially as they can give their views on draft legislation and monitor the respect of the principle of subsidiarity. The Council can adopt a proposal if a qualified majority of Member States supports it. Areas where the need for EU criminal law has been established are, for example, the protection of the functioning of the financial markets, the protection of the euro against counterfeiting or the fight against fraud to the detriment of the EU budget. EU criminal law measures can define which violations of the rules are to be considered as criminal offences in national laws throughout the Union. They can also provide for effective, proportionate and dissuasive criminal sanctions, such as requiring the imposition of certain levels of monetary fines or imprisonment for an offence ${ }^{24}$.

24 Towards a reasonable use of criminal law to better enforce EU rules and help protect taxpayers' money', European Commission Press Release (http://europa.eu/rapid/press-release_IP-11-1049_en.pdf) 


\section{THE CONCEPT OF CRIME. GENERAL PRINCIPLES OF CRIMINAL LAW}

The Concept of Crime. There are formal and material definitions of what constitutes a crime. In many countries a formal definition of the crime is used, according to which an act is considered to be a crime if it is provided by the Criminal Code of the certain country. A material definition of the crime includes features that determine why a certain act is a crime. First of all, it is an indication on public harm and perpetrators. Social harm, culpability and the committal of an illegal act by an offender are the material elements of the crime that reveal both external and internal socio-psychological nature of the crime; the prediction of act by the Criminal Code is a formal sign that reflects the legal, regulatory nature of the crime, in other words its illegality.

The characteristic of a crime as an act or omission (a failure to act where the law imposes a duty to act) is essential. Crime as a conscious act of volition of the individual is to be found in a particular act or omission. Views, opinions or believes that have not found its expression in an act or omission, even if they are contrary to the public interest, are not considered to be a crime. At the same time a particular act or omission deprived of the psychological basis of the act, its conscious and volitional elements (e.g. reflex, instinctive behavior) is not a crime.

Social harm as a material sign of crime means that an act brings harm to the relationships protected by the criminal law or contains a real possibility of causing such harm. This is an objective sign / of a crime, i.e. actual infringement of relations existing in society. Emergence, change, loss of social harmfulness of the act is caused by objective laws of social development, the indissoluble connections of the social and economic processes taking place in society. The evaluation of social harm of an act as a feature of a crime takes place on two levels: firstly, at the legislative level, when the legislators establish the acts which are considered to be dangerous in the Criminal Code, and secondly, at the procedural level, when an inquisitor, a prosecutor or a judge estimates the social danger of the crime. Traditionally, crimes have been restricted to acts and omissions that harm the interests of others. Sometimes, however, a legislature will criminalize an act or omission because it is harmful to the perpetrator himself, or because the conduct is morally 
reprehensible. Such criminal provisions are known as "victimless" crimes. The possibility of a victimless crime underscores the central difference between criminal and civil law: a crime is an offense against public welfare, whereas a civil wrong is an offense against private interests. While civil damages are awarded to compensate a victim for harm he has suffered at the injurer's hands, criminal punishment is inflicted to allow the state to vindicate its interest in the common good.

Civil and criminal divide. In recent years, the distinction between civil and criminal wrongs has become somewhat blurred $^{25}$. On the civil side, for example, there is the institution of "punitive damages," by which an individual is punished for the intentional infliction of an injury or a malicious breach of contract. Punitive damages are intended as punishment for the injurer, unlike the ordinary civil remedy of compensatory damages that cannot exceed the amount required to make the victim whole. On the criminal side, there is the increasingly common use of monetary penalties in lieu of incarceration. Such penalties are often paid as compensation to the victim in the form of restitution. There is also increasing use of the criminal sanction against corporations. Since a corporation can only be punished with monetary sanctions, and since punitive damages are increasingly awarded in civil suits, the distinction between civil and criminal in such cases is a nominal one. It would appear to consist mostly of procedural differences, such as the different standards of proof and different rules of evidence. Finally, there is a recent movement to enhance the role of the victim in criminal proceedings, stemming from the belief that crime victims have a right to representation in the prosecution of their attackers. The idea of victim's rights most strongly suggests a shift away from the conception of crime as a public offense. It suggests that the punishment of the offender serves, at least in part, to satisfy the victim's need for vengeance. This trend toward the "privatization" of crime finds expression in various proposed institutional reforms as well, such as the proposal to convert prisons to private ownership.

The acceptability of these various modifications of the traditional notion of crime depends partly on what we take a crime to be. Is a crime simply a prohibition that appears in one of

25 Claire Finkelstein. Encyclopedia of Crime and Justice // http://www.encyclopedia.com/law/legal-and-political-magazines/crime-definition 
the state or federal penal codes under the heading "criminal"? Or is the criminal category a deeper one, one that does not derive its meaning from any particular use to which the notion of crime is put? The first would be what we might call a "positivistic" stance toward the notion of an offense. It treats crime entirely as a legislative concept. The second would be a normative stance toward the notion of an offense identifying the criminal category by a theory of justified prohibition. On a positive approach, there can be no objection to punishing corporations or enhancing the role of the victim, since there is no obligatory content to the notion of an offense. On a normative approach, by contrast, there may be grounds for objecting to these modifications to the traditional treatment of crime. For it may turn out that punishing an offender at the behest of the victim, especially if associated with the payment of restitution, is not legitimate according to our best theory of justified punishment ${ }^{26}$.

Many decisions of the European Court of Human Rights in the context of Art. 6 of Convention on Fundamental Rights and Freedoms of 1950 are also devoted to the issue of separating a criminal act from a non-criminal one. So, in the case of Engel v. Netherlands there are established 3 criterion of the definition of "criminal" within the context of Art. 6 of the Convention: 1) classification of the crimes within the laws of the country; 2) the specific nature of a crime; 3) a possible penalty. In the case of Funke v. France it was stated that if the state defines the offense as a criminal one, it is automatically considered as the one within Art. 6. However, the lack of categorization of criminal offense under the country law is relative; in such cases, the second and third criteria, defined in the case of Engel (Weber v. Switzerland, $\S \S 32-34$ ) is used. It is stated in the decision on this case that the nature of a crime is a more important criterion than the one of classification of the offense within the laws of the country. In such cases the comparison of national legislation and the boundaries of its application in relation to other offenses, that are recognized under this criminal legal system, is carried out (Engel, $\S \S 80-85)$. In the case of Campbell and Fell v. the United Kingdom $(\S 101)$ it is stated that the fact of orientation of the offense on a wide sector of the population is just one of the criteria that usually indicates criminality; a high severity of a

${ }^{26}$ Claire Finkelstein. Encyclopedia of Crime and Justice // http://www.encyclopedia.com/law/legal-and-political-magazines/crime-definition 
crime is another criterion. At the same time, the insignificance of the act does not mean impossibility of using Art. 6, as "criminal" nature of the offense does not necessarily imply a certain degree of its severity (Ozturk, § 53). The third criterion is applied in a cumulative way, when it is impossible to come to a conclusion by applying the first and second criteria (Ezeh and Connors, $\S \S 108-130)$, or as an alternative criterion that proves "criminality", even if the nature of the offense is not necessarily "criminal" (Engel). The penalty, which involves sentencing to an imprisonment even for a short time, almost automatically makes a proceeding "criminal." In the case Zaicevs v. Latvia (§ § 31-36) the three days of the "administrative detention" for the disrespect to the court were viewed as carrying the offense to a "criminal sphere" (as the case Menesheva v. Russia, § § 94-98).

Therefore, by definition, a crime is any:

legally proscribed (the concept of Legality)

human conduct (the concept of Actus Reus)

causative (the concept of Causation)

of a given harm (the concept of Social Harm)

which coincides with (the concept of Concurrence)

a blameworthy frame of mind (the concept of Mens Rea)

for which punishment is provided. (the concept of

Punishment)

So government is not concerned with evil unless it is manifested in behavior.

Action is always conscious, voluntary, and purposive behavior. There's a line in Shakespeare's Hamlet where the gravedigger ponders Ophelia's drowning, and asks "Did the water come to Ophelia or did Ophelia come to the water." The difference is one of accidental death vs. suicide ${ }^{27}$.

Due to internationally recognized doctrine general principles of criminal law are 28 :

Nullum crimen sine lege A person shall not be criminally responsible under the criminal law unless the conduct in question constitutes, at the time it takes place, a crime within the jurisdiction of the concrete Court. The definition of a crime

\footnotetext{
${ }^{27}$ No personalities involved no appeals to tradition // https://www.coursehero.com/file/p3gikv/No-personalities-involved-No-appealsto-tradition-Just-stone-cold-professionals /

28 Nullum Crimen, Nulla Poena Sine Lege in War Crimes Trials // http://www.umac.mo/fll/doc/Nullum\%20Crimen_Nulla\%20Poena\%20Sine\%20L ege\%20in\%20War\%20Crimes\%20Trials.pdf
} 
shall be strictly construed and shall not be extended by analogy. In case of ambiguity, the definition shall be interpreted in favor of the person being investigated, prosecuted or convicted.

Nulla poena sine lege A person convicted by the Court may be punished only in accordance with the criminal law.

Non-retroactivity ratione personae No person shall be criminally responsible under the criminal law for conduct prior to the entry into force of the Law. In the event of a change in the law applicable to a given case prior to a final judgement, the law more favourable to the person being investigated, prosecuted or convicted shall apply.

Individual criminal responsibility The Court shall have jurisdiction over natural persons pursuant to the criminal law. A person who commits a crime within the jurisdiction of the Court shall be individually responsible and liable for punishment in accordance with the criminal law. In accordance with the criminal law, a person shall be criminally responsible and liable for punishment for a crime within the jurisdiction of the Court if the person:

(a) Commits such a crime, whether as an individual, jointly with another or through another person, regardless of whether that other person is criminally responsible;

(b) Orders, solicits or induces the commission of such a crime which in fact occurs or is attempted;

(c) For the purpose of facilitating the commission of such a crime, aids, abets or otherwise assists in its commission or its attempted commission, including providing the means for its commission;

(d) In any other way contributes to the commission or attempted commission of such a crime by a group of persons acting with a common purpose. Such contribution shall be intentional and shall either: i) be made with the aim of furthering the criminal activity or criminal purpose of the group, where such activity or purpose involves the commission of a crime within the jurisdiction of the Court; or (ii) be made in the knowledge of the intention of the group to commit the crime;

(e) Attempts to commit such a crime by taking action that commences its execution by means of a substantial step, but the crime does not occur because of circumstances independent of the person's intentions. However, a person who abandons the effort to commit the crime or otherwise prevents the completion of the crime shall not be liable for punishment under this Statute 
for the attempt to commit that crime if that person completely and voluntarily gave up the criminal purpose.

Exclusion of jurisdiction over minors The Court shall have no jurisdiction over any person who was under the age of the criminal law limits at the time of the alleged commission of a crime.

Irrelevance of official capacity The criminal law shall apply equally to all persons without any distinction based on official capacity. In particular, official capacity as a Head of State or Government, a member of a Government or parliament, an elected representative or a government official shall in no case exempt a person from criminal responsibility under this Statute, nor shall it, in and of itself, constitute a ground for reduction of sentence. Immunities or special procedural rules which may attach to the official capacity of a person, whether under national or international law, shall not bar the Court from exercising its jurisdiction over such a person.

Mental element Unless otherwise provided, a person shall be criminally responsible and liable for punishment for a crime within the jurisdiction of the Court only if the material elements are committed with intent and knowledge. A person has intent where:

(a) In relation to conduct, that person means to engage in the conduct;

(b) In relation to a consequence, that person means to cause that consequence or is aware that it will occur in the ordinary course of events ${ }^{29}$.

\footnotetext{
${ }^{29}$ Mental and material elements of crimes // http://law.lu.se/WEBUK.nsf/ (MenuItemByDocId)/ID9F3EAD7CFF4FCDFCC1257FB8003681A2/\$FILE/Mental \%20Element.pdf
} 


\section{CORPUS DELICTI. THE BASICS OF CRIMINAL LIABILITY}

Corpus delicti literally means the body or substance of the crime. In law the term refers to proof establishing that a crime has occurred. Although misunderstanding about corpus delicti has been common, the term does not refer to a dead body. There is a corpus delicti of robbery, tax evasion, and, indeed, of every criminal offense. Moreover, even in a homicide case, a "dead body" is neither necessary nor sufficient to establish the corpus delicti. Testimony that a ship's passenger pushed the deceased overboard can establish the corpus delicti of murder even if the body is never recovered. Conversely, the body of a child killed in a fire would not establish the corpus delicti of murder, absent proof that the fire was caused by some criminal act ${ }^{30}$.

When a failure to prove some fact essential to the charge implies that the offense was not committed by anyone, the courts sometimes say that reversal of the conviction is required by the absence of a corpus delicti. It would be equally accurate, and less mysterious, to say simply that the reversal results from the prosecutor's failure to prove an essential element of the case. The principal significance of corpus delicti is its effect on the admissibility of evidence. Under

the traditional rule, still followed in most states of the USA, a confession is inadmissible unless there is independent evidence of a corpus delicti. But some American jurisdictions now reject this traditional rule. In federal courts and in several states, a confession is admissible if its trustworthiness is established, even without independent proof of a corpus delicti. Some commentators argue that this approach offers a better way to meet concerns about the truthfulness of a confession.

Many murder convictions have been obtained even though the body of the alleged victim was never found. In several early cases, dating from the seventeenth century and before, the "deceased" turned up alive and well shortly after the defendant had been executed. Such miscarriages of justice contributed to the development of the rule requiring independent corroboration of any confession. In the modern era, numerous murder convictions

\footnotetext{
30 Stephen J. Schulhofer. Corpus Delicti - Bibliography // http://law.jrank.org/ pages /753/Corpus-Delicti.html
} 
continue to be found by juries and upheld by the courts even in the absence of a dead body. In nearly all of these cases the defendant confessed, and the proof of corpus delicti, together with the defendant's direct admissions, afforded strong evidence of guilt.

More troublesome, and less common, are murder prosecutions in which there is no dead body, no confession, and no eyewitness to the alleged crime. In these cases the proof of guilt is necessarily "circumstantial"-that is, based entirely on inferences drawn from suspicious facts. Although the potential for a miscarriage of justice in such cases is evident, the legal system must have some means for dealing with the offender who is able to obliterate all trace of the victim. In many cases, circumstantial evidence of guilt has been held sufficient to warrant a conviction of murder, even though neither a dead body, a confession, nor an eyewitness was available ${ }^{31}$.

The notions of a crime and corpus delicti are in indissolubly connected. A body of a crime is a legislatively fixed form of generalized features of some types of a crime. The notions of a crime and body of a crime are closely connected with each other, but are not identical. The material definition of crime is the basis and the juridical construction of the body of any particular crime and uncovers the its necessary features. The notion of crime is concretized in the criminal legislation in the form of corpus delicti of particular crimes. The body of crime is a set of objective and subjective features, established by the law, which characterize a socially harmful action as a crime. The body of crime is to be called not only a set of features, but their system. The absence of any element in the body of crime breaks the whole system. The body of crime is a legal notion of crime. The elements of the body may contain obligatory and optional features, which depends on a particular crime body. Bringing a person to a criminal liability and its right qualification is impossible without determination of the obligatory features of the crime body. A crime qualification is a logical process of the determination of all the necessary crime features and their identification with the features of a particular crime body, which is fixed in penal norms.

Criminal Liability. The question of criminal liability is the most difficult in the science of criminal law, as there is no legal

${ }^{31}$ Stephen J. Schulhofer. Corpus Delicti - Bibliography // http://law.jrank.org/ pages /753/Corpus-Delicti.html 
definition of criminal responsibility, therefore in the legal literature there are many points of view on this issue.

Quite common is the view that a criminal penalty, acting as a kind of social responsibility, is a dialectical combination of two aspects - the negative (retrospective) and positive (prospective).

Concerning identifying of negative (retrospective) criminal offenses there are such points of view:

1) criminal liability is equated with punishment

2) criminal liability is defined as a conviction of a person for the offense

3) criminal liability is understood as the obligation of the person who committed the crime to undergo adverse consequences

4) criminal liability is treated as an actual undergoing of coercive measures applied to the perpetrator

5) criminal liability is actually identified with criminal relationship or as a set of criminal and other legal relations

6) criminal liability is considered an object of criminal relationship and criminal relationship and is defined as the limitation the legal status of a citizen accompanying public censure, which he is subject by law because of having committed a crime.

In the criminal law doctrine there are three basic points of view on the grounds of criminal responsibility: crime, culpability, and body of a crime. However, the fact of committing a crime is not enough for bringing somebody to criminal liability, because it may appear that the person who committed it acted with the absence of culpability or isn't a proper perpetrator (an insane one or the one who has not reached the age of criminal responsibility).

Culpability itself does not serve as grounds for criminal liability, as it is only one of the components of corpus delicti. Therefore, a common standpoint is the point of view of authors, who define an act that contains the essential elements of the crime as the basis of criminal liability. So the presence of the features of a certain body of crime provided by the criminal law in a particular act of crime is the basis for criminal liability.

Legislature (normative) description of the specific features of bodies of crime in its entirety establishes the minimum of features that allows one to separate the criminal act from the non-criminal. Having this set of characteristics of a criminal act in the behavior of the offender is the only and enough reason for 
making a decision on the possibility of bringing a person to criminal responsibility for the commission of a particular act.

There is no single point of view on the boundaries of criminal liability. The current points of view can be divided into the following groups:

1. The beginning of criminal liability is the moment of committing a crime, the ending is the cancellation of conviction or clearance of records of conviction, or sometimes - just serving the sentence;

2. The beginning of criminal liability is the moment of committing a crime, the ending of the criminal responsibility is conviction of a court for sentencing;

3. The beginning of criminal liability is the moment of application of the methods of procedural enforcement to the offender, the ending is the cancellation of conviction or clearance of records of conviction, sometimes - just serving the sentence;

4. The beginning of criminal liability is the moment of a verdict of guilty coming into force, the ending of criminal liability is the cancellation of conviction or clearance of records of conviction, sometimes - just serving the sentence;

5. There are two boundaries of the criminal liability - serving the sentence and the period of the expiry of a record.

Criminal liability is what unlocks the logical structure of the Criminal Law. Each element of a crime that the prosecutor needs to prove (beyond a reasonable doubt) is a principle of criminal liability. There are some crimes that only involve a subset of all the principles of liability, and these are called "crimes of criminal conduct". Burglary, for example, is such a crime because all you need to prove beyond a reasonable doubt is an actus reus concurring with a mens rea. On the other hand, there are crimes that involve all the principles of liability, and these are called "true crimes". Homicide, for example, is such a crime because you need to prove actus reus, mens rea, concurrence, causation, and harm. The requirement that the prosecutor must prove each element of criminal liability beyond a reasonable doubt is called the "corpus delicti rule"32.

\footnotetext{
32 Principles of Criminal Liability // http://josephatpublic.blogspot.com/ p/criminal-liability.html
} 


\section{ACTUS REUS - GENERAL CHARACTERISTICS OF OFFENSIVE CONDUCT}

The actus reus of an offense is the physical, or external, component of a crime that includes socially dangerous conduct (act or omission) which results in socially dangerous consequences or creates the danger of their forthcoming. Actus reus includes the following components: socially dangerous conduct (act or omission), socially dangerous consequences, causation of socially dangerous consequences and conduct, as well as crime scene, time, modus operandi, circumstances of committing a crime ${ }^{33}$.

Socially harmful conduct is always an obligatory feature of the objective side of crime body regardless of the structure of the body. With so-called "result" crimes, consequences and causation are also obligatory features of crime body along with socially dangerous conduct. Crime scene, time, way, circumstances of committing a crime may be obligatory features, if they are mentioned directly in the article disposition, but more often they are optional features of a body of a crime.

Generally speaking, there can be no crime in the absence of conduct. But, only a certain type of conduct qualifies, namely, conduct that includes a voluntary act. In rare circumstances, a person may be prosecuted because of what he or she did not do-an absence of conduct. An "omission" substitutes for a voluntary act when the defendant has a legal duty to act. People are not punished for conduct (or omissions), but rather for conduct (or omissions) that result in "social harm." 34

A person is not ordinarily guilty of a criminal offense unless his conduct includes a voluntary act. In Common Law, a "voluntary act" is a willed muscular contraction or bodily movement by the actor. An act is "willed" if the bodily movement was controlled by the mind of the actor.

The Model Penal Code developed by the American Law Institute does not define "voluntary act". It provides examples of involuntary actions: a reflex or convulsion; bodily movement while unconscious or asleep; conduct during hypnosis or as a result of hypnotic suggestion; and/or "a bodily movement that

33 Elements of a Criminal Offence // https://www.tutorhunt.com/resource/ $2720 /$

34 Joshua Dressler. Criminal Law // http://euro.ecom.cmu.edu/program/law/ 08-732/Types/DresslerCriminal.pdf 
otherwise is not a product of the effort or determination of the actor, either conscious or habitual."

The Supreme Court of the USA has never expressly held that punishment of an involuntary actor is unconstitutional. However, it has invalidated statutes that criminalize a "status" or "condition" (such as being a drug addict), rather than conduct.

To be guilty of an offense, it is sufficient that the person's conduct included a voluntary act. It is not necessary that all aspects of his conduct be voluntary. A person who acts involuntarily cannot be deterred. Therefore, it is useless to punish the involuntary actor. It results in pain without the benefit of crime reduction. A more persuasive justification for the voluntary act requirement is that blame and punishment presuppose free will: a person does not deserve to be punished unless she chooses to put her bad thoughts into action ${ }^{35}$.

Omission. Ordinarily, a person is not guilty of a crime for failing to act, even if such failure permits harm to occur to another, and even if the person could act at no risk to personal safety. Criminal conduct requires a guilty state of mind (mens rea). It is unusually difficult to determine the state of mind of one who fails to act. Difficult line-drawing problems-which omitters should be prosecuted? - arise in omission cases. In a society such as ours, premised on individual liberties and limited government, the criminal law should be used to prevent persons from causing positive harm to others, but it should not be used to coerce people to act to benefit others. Notwithstanding the general rule, a person has a legal duty to act in limited circumstances, if he is physically capable of doing so.

Crimes of omission: statutory duty. Some statutes expressly require a person to perform specified acts. Failure to perform those acts, by definition, constitutes an offense. Such an offense may be characterized as a "crime of omission."

Crimes of commission. The criminal law sometimes permits prosecution for a crime of commission (an offense that, by definition, appears to require proof of conduct, rather than an omission), although the basis of the prosecution is an omission. Thus, we have a case of what might be characterized as commission-by-omission.

35 Joshua Dressler. Criminal Law // http://euro.ecom.cmu.edu/program/ law/08-732/Types/DresslerCriminal.pdf 
- Duty by status. A person has a common law duty to protect another with whom he has a special status relationship, typically, one based on dependency or interdependency, such as parent-to-child, spouse-to-spouse, and master-to-servant.

- Duty by contract. A person may have an express contract to come to the aid of another, or such a contract may be implied-inlaw.

- Duty by voluntary assumption. One who voluntarily assumes the care of another must continue to assist if a subsequent omission would place the victim in a worse position than if the good samaritan had not assumed care at all.

- Duty by Risk Creation. One who creates a risk of harm to another must thereafter act to prevent ensuing harm ${ }^{36}$.

Social Harm. "Social harm" may be defined as the destruction of, injury to, or endangerment of, some socially valuable interest. You can determine the "social harm" of an offense by looking at the definition of the crime and identifying the elements of it that describe the external conduct that constitutes the crime ${ }^{37}$.

The social harm of crime may be various, it may take place in different spheres of economics, human rights, ecology and so on. It can be subdivided into two big groups: harm of tangible and intangible nature.

Tangible harm includes property damage, for example, in crimes against property, and damage with personal (physical) nature as well, like body injuries. Consequences of tangible nature may appear as a so-called positive loss or loss of profits (unearned income). Intangible harm may be defined as negative changes in the object of encroachment, which are connected with the violation of interests of members of social relations protected by the criminal law, and, as a rule, do not include physical influence on a person or material objects of the outer world. Here we may speak of political harm (crimes against national security), organizational harm (crimes in the sphere of official activities, military crimes, crimes against justice, public safety, peace), social harm (crimes against labor and electoral rights of citizens).

According to the type of a particular object, which is harmed by criminal conduct, harm may be subdivided into primary and secondary harm. So, the harm that is done to the normal functioning of the state apparatus by a crime of excess of power

\footnotetext{
36 Joshua Dressler. Criminal Law // http://euro.ecom.cmu.edu/program/ law/08-732/Types/DresslerCriminal.pdf 37 Ibid.
} 
would be a primary consequence, while the harm that is done to a person, if excess is accompanied by violence or painful or offensive actions, would be the secondary harm. At the same time secondary consequences may be subdivided into obligatory ones, i.e. those that always take place in every case of crime commission (for example, harm to the victim's health during a robbery with violence), and optional, which may or may not take place during crime commission (for example, harm to an individual or to property when committing hooliganism).

It is sometimes essential for a lawyer (especially in jurisdictions that follow the Model Penal Code) to be able to look at the definition of a crime, more specifically the actus reus portion, and divide up the "social harm" elements into one or more of the following three categories.

1. "Result" Elements (or Crimes). Some crimes prohibit a specific result, such as the death of another person.

2. "Conduct" Elements (or Crimes). Some crimes prohibit specific conduct, whether or not tangible harm results thereby, such as offenses that prohibit drunk driving.

3. "Attendant Circumstance" Elements. A "result" or "conduct" is not an offense unless certain "attendant circumstances" exist. An "attendant circumstance" is a fact that exists at the time of the actor's conduct, or at the time of a particular result, and which is required to be proven in the definition of the offense ${ }^{38}$.

Causation. In criminal law, causation is an objective connection between socially dangerous conduct and harm. Causation needs to be proved as an element of the objective side of crime in cases, when social harm is an obligatory element of corpus delicti, i.e. with "result" crimes. We may speak of causation only in cases, when actions appear to be the necessary condition of harm, and without them harm would be impossible. This implies the following most important requirements: 1) the cause must precede the consequence; 2) the cause must not only precede the consequence, but entail it; 3) causation takes place only in case when actions are the main condition which determines social harm; 4) actions are in casual connection with harm, if the inevitably cause arising of this harm.

Actual cause (cause-in-fact). A person is not guilty of an offense unless she is an actual cause of the ensuing harm. Both

\footnotetext{
38 Joshua Dressler. Criminal Law // http://euro.ecom.cmu.edu/program/ law/08-732/Types/DresslerCriminal.pdf
} 
the common law and the Model Penal Code provide that conduct is the "actual cause" of the prohibited result if the result would not have occurred but for the actor's conduct ${ }^{39}$.

To Identify the Relevant Conduct, one has to determine what is (are) the relevant voluntary act(s) committed by D. If the case is based on an omission, one has to determine what the omission is, and substitute that for the "voluntary act" in the following discussion.

The question should be asked: "But for D's voluntary act(s) would the social harm have occurred when it did?" If the social harm would have occurred when it did even if D had not acted, $\mathrm{D}$ is not the actual cause of the harm and, therefore, is not guilty of the offense. In a sense, "yes" means "no" (no criminal liability). If the social harm would not have occurred when it did but for D's voluntary act(s), D is an actual cause of the social harm, in which case you move on to the remaining causation issue (proximate cause).

There usually are multiple actual causes of a result. A person who dies of lung cancer, for example, might not have died when she did but for her smoking habit and living in a smog-polluted city. It can also be the case that two persons-two potential defendants-are the actual cause of a result.

In rare circumstances, the "but for" test may fail to reach the morally sensible result. The problem arises when two acts, either one of which is sufficient to cause the resulting harm when it did, occur concurrently. In such cases, many courts resort to the "substantial factor" test, a standard that is often used in tort cases. The question to be asked is: "Was D's conduct a substantial factor in the resulting harm?" The MPC does not apply the substantial factor test-it uses the "but for" test in all cases. However, the Commentary to the Code explains that, in deciding whether a defendant was a "but for" cause of a "result," one would state the "result" with great specificity"

Proximate cause (legal cause). A person who is an actual cause of resulting harm is not responsible for it unless she is also the proximate (or "legal") cause of the harm. When the law states that a defendant was the proximate cause of a result, this is a shorthand way of saying that it is morally just to hold this person responsible for the harm.

39 Joshua Dressler. Black Letter Outline on Criminal Law // https:// books.google.com.ua/books?id=HFzaCgAAQBAJ\&pg=PT268\&lpg=PT268\&dq 40 Ibid. 
As with any "what is just" analysis, there is no single or straightforward answer. The common law provides various potential factors to consider. The drafters of the Code have another way of handling the issue: they treat "proximate causation" as a culpability, rather than causal, issue. The MPC issue is whether the defendant can be said to have purposely, knowingly, recklessly, or negligently (whichever is relevant in a particular case) caused "a particular result" if the "result" occurs in an odd or unexpected manner. The Code takes all of the common law factors discussed below and basically rolls them into one, explicit, policy question for the jury: Was "the actual result...too remote or accidental in its occurrence to have a [just] bearing on the actor's liability or on the gravity of the offense." 41

A direct cause is a but-for cause, in which no other cause intervenes between it and the resulting social harm. A voluntary act that is a direct cause of the social harm is also a proximate cause of it. This is because there is no other candidate for causal responsibility.

An "intervening cause" is an actual cause (a "but for" cause) of social harm that arises after D's causal contribution to the result.

An intervening cause does not necessarily relieve a defendant of causal responsibility for the resulting harm. At common law, various factors come into play in proximate causation analysis. It is useful, although not always dispositive, to determine whether the intervening cause was "dependent" or "independent" of the defendant's act. An intervening cause is dependent if it occurs in response to the defendant's earlier conduct. An intervening cause is independent if the factor would have come into play even in the absence of the defendant's conduct.

Generally speaking, a defendant is responsible for a dependent intervening cause, unless the dependent intervening act was not only unforeseeable but freakish. In contrast, a defendant is not ordinarily responsible for an independent intervening cause, unless its occurrence was foreseeable to a reasonable person in the defendant's situation.

In general, a defendant is the proximate cause of a result, even if there is an intervening cause, if the defendant intended the result that occurred. But, one should be very precise in

41 Joshua Dressler. Black Letter Outline on Criminal Law // https: / / books.google.com.ua/books?id=HFzaCgAAQBAJ\&pg=PT268\&lpg=PT268\&dq 
stating what result the defendant intended: a person may want someone dead in a particular manner, in which case this doctrine only applies if the result occurs in the desired manner.

In general, a defendant is not the proximate cause of a result if a free, deliberate, and informed act of another human being intervenes.

Even though the defendant has created a dangerous situation, she is not responsible for the ensuing result if it can be determined that the dangerous situation created by the defendant is over-that the victim, once at risk, has reached apparent safety ${ }^{42}$.

\section{OBJECT MATTERS OF CRIME}

In Ukrainian doctrine one said about object and object matters of crime as elements of criminal liability.

The concept of the object of crime and its place in the crime matters, the mechanism of criminal influence on the object, the delineation of the object of crime from tools and means of crime, as well as other issues remain controversial in the science of criminal law.

The object of the crime is the criminal law protected by the social relations, on which the criminal offense is committed. Such social relations are: social order, political and economic system of the state, relations of property, personality, political, labor, property and other rights and freedoms of citizens and the rule of law. At the same time, there are different from this concept of the object of the crime. Thus, the object of crime is recognized by law and order; benefits (interests), which are criminalized and protected by criminal law; the order of public relations, protected by a criminal law, etc.

By "vertical" the object of the crime is divided into the following types: general, generic, species, direct.

The general object is the entire set of criminal laws protected by public relations. It should be clarified that with the help of criminal law, not all social relations are protected. The legislator has placed under the protection of the criminal law only the most important of them, which causes significant damage as a result of criminal encroachment. The service function of the general

42 Joshua Dressler. Black Letter Outline on Criminal Law // https://books.google.com.ua/books?id=HFzaCgAAQBAJ\&pg=PT274\&lpg=PT274\&dq 
object consists not only in the fact that it combines social relations, which are generic, direct objects, but also that it expresses their main property - belonging to one of the most important relations protected at this stage of development of society. The general object is important for determining the sociopolitical nature of the crime, the degree of their social danger and allows to distinguish between crimes from other offenses that are the subject of other branches of law.

General object - a set of homogeneous social relations, which is impeded by a certain group of homogeneous crimes. The group of social relations is carried out on the basis of objectively existing criteria that determine their homogeneity. On the principle of general object the system of the Special Part of the Criminal Law was built. The establishment of a general object allows us to emphasize the importance of the social relations that it combines in the interests of the state and society, and determines the nature and extent of the social danger of criminal encroachments. Establishing these circumstances makes possible to identify the social role of criminal law in the protection of certain public relations. Specific object - a set of identical social relations, protected by criminal law. The specific object correlates with its general object, as part of the whole or as a species with a genus. In a large group of family-related social relations that deserve a single, comprehensive criminal-law protection (general object) allocate a narrower group of relations (a specific object).

The direct object is the concrete social relations on which the criminal offense is committed. The direct object, in turn, is subdivided into: the main and the additional, and the additional direct object there are 2 types: additional compulsory and additional optional. The main direct object always lies in the plane and is part of the general object of the crime, it is the most important, that determines the social danger of a particular crime, the structure of the corresponding composition and its place in the system of the Special Part of the Criminal Code. Establishing this object in a specific crime allows you to correctly select the necessary criminal norm and qualify the crime. The main direct object is social relations, that, first of all, sought to be protected by the legislator, passing a criminal law. An additional direct object is those social relations, which also cause damage during a criminal encroachment, but they are an integral part of another general object. An extra-mandatory object is 
always harmed along with the main object. Additional-optional object is recognized by the criminal law protected social relations, which not in all cases causes harm during the commission of a crime.

The objective aspect of the crime is the external aspect of a crime characterized by a criminal act (action or inactivity), which results in certain socially dangerous consequences or threatens their atrocities.

The objective side of the crime is determined by the following features: socially dangerous act (action or indecisiveness), socially dangerous consequences, causal connection between the act and socially dangerous consequences, place, time, way, situation of the crime, means and tools of committing a crime.

Socially-dangerous act is always a mandatory indication of the objective side of the crime regardless of the structure of the composition. In material stores, along with socially dangerous acts, the consequence and causal connection are also obligatory features of the crime. The place, time, method, situation of the crime, means and instruments may be obligatory if they are expressly indicated in the disposition of the article, but more often they act as an optional indication of the objective aspect of the crime.

A socially dangerous act can be either in the form of active actions, or in the form of passive inaction. Responsibility for criminal inaction occurs when the person should and could act in a certain way. The duty (duty) to act may give rise to various grounds: laws, regulations, contract, professional or service functions, family relationships, voluntary commitments that precede or accompany events. The presence of a real opportunity to act in a certain way depends on certain characteristics of the person in this particular situation.

Socially-dangerous acts (acts or inactivity) are voluntary actions of a person who represent a psychophysical connection between the external and internal sides of his behavior. However, there are situations where volitional factor is absent or paralyzed. These circumstances include: irresistible force, physical or mental coercion.

Socially-dangerous consequences are defined as damage (damage), which is caused by a criminal act of social relations. The consequences of the crime are diverse, they can take place in various spheres of economy, human rights, ecology, etc. All of 
them can be subdivided into two large groups: the consequences of material and immaterial nature.

Material consequences include property damage, for example, in property offenses, as well as damage that is personal (physical), such as bodily injury.

In turn, the criminal consequences of the property nature may be expressed in the so-called positive loss or missed profit (unearned income). Intangible consequences are such negative changes in the object of encroachment, which are connected with violation of those or other interests of participants in public relations, protected by criminal law, and, as a rule, are not related to physical influence on a person as a subject social relations or influence on the material objects of the external world (good), about which there are social relations. Here, political damage (crimes against the national security of the state), organizational (crimes in the sphere of official activity, war crimes, against justice, public safety, public order), social (crimes against labor). Depending on the type of immediate object to which the socially dangerous act causes harm, the consequences can be subdivided into the main and additional. Thus, the damage caused by an official to the normal activities of the state apparatus in excess of the authority or official authority is the main, and the damage caused to the individual, if the excess is accompanied by violence or painful, or such as adversely affecting the dignity of the victim, by actions, an additional consequence. At the same time, additional consequences can be subdivided into obligatory (optional), that is, those that always occur, in all cases when the crime is committed, for example, damage to the health of the victim at the time of robbery, and optional (optional optional) that may occur, but may also be absent in the commission of the crime, for example, damage to personality or property in the course of committing hooliganism.

The onset of the consequences specified in the law in some cases is a necessary sign of the basic (simple) composition of the completed crime, for example, the spread of epizootics or other grave consequences as a result of violation of veterinary rules; in others, socially dangerous consequences play the role of qualifying circumstances, which aggravates the responsibility, for example, destruction or damage to the forests, which has caused grave consequences. Some norms of the Criminal Code attribute criminality and punishment to an act with the obligatory onset of certain socially dangerous consequences. 
Causal link in criminal law is an objective connection between socially dangerous acts and the consequences. Causal communication as a sign of the objective side of the crime is to be established in cases where socially dangerous consequences are a mandatory feature of the crime, that is, in crimes with material composition.

Causal connection takes place only when the act acts as a necessary condition without which it is impossible to have a consequence. From this follows the most important requirements: 1) the cause (act) in time should precede the result; 2) the cause (act) not only must precede the consequence in time, but also cause it; 3) a causal connection occurs only when the act is the main condition for the occurrence of a socially dangerous consequence; 4) the act is in a causal connection with the consequence, if it inevitably causes the onset of this consequence.

The necessary causal connection should be distinguished from the occasional causal connection. The necessary causal relationship reflects the laws of the development of the objective world, when the reason itself contains the real possibility of a certain consequence. With the necessary causal connections, the person, knowing the objective world, can predict the development of the natural course of events. By doing those or other actions that regularly cause the consequences, it can predict the onset of these consequences.

Random causal relationships do not reflect the patterns of the development of events. They are the result of accidental crossing of causative links. For example, the victim, who suffered a slight injury, died from the fact that he had been infected during the dressing. Responsibility in this case can occur only in case of injury. 


\section{PERSONALITY OF A CRIMINAL AS CRITERIA OF CRIMINAL LIABILITY INDIVIDUALIZATION}

The personality of a perpetrator plays an important role for when determining of the nature of a particular crime, imposing a sentence, differentiating between contiguous crimes and also when differentiating between crimes and other offences. Besides, the features of a perpetrator are taken into account when resolving the question of release from criminal responsibility or penalty. By analyzing the personality of a perpetrator, one can determine the social threat/danger of the committed crime.

Only a person who could be aware of the socially harmful nature of his actions and could control them while committing a crime, that is a criminally sane or partially sane person who reached a certain age determined by criminal law, can be considered a perpetrator. Only a person, who committed socially harmful act can be a perpetrator.

One of the fundamental presumptions of the criminal law and criminal liability is that the defendant is 'normal', i.e. is able to function within the normal range of mental and physical capabilities. We have seen that many of the principles of individual fairness presuppose an individual who is rational and autonomous: otherwise he does not deserve to be liable to criminal punishment. A person who is mentally disordered may fall below these assumed standards of mental capacity and rationality, and this may make it unfair to hold him responsible for his behaviour. It is for this autonomy-based reason that most systems of criminal law contain tests of 'insanity' which result in the exemption of some mentally disordered persons from criminal liability. The same rationale may be given for the voluntariness requirement. There is also the prior question of whether the defendant is fit to be triedwhether the person can participate in the trial in a sufficiently meaningful sense. It is an essential precondition of a criminal trial, as Antony Duff has argued, that the defendant is a responsible citizen who is answerable before the court. The doctrine of 'unfitness to plead' embodies a procedural attempt to deal with this in relation to mentally disordered defendants. Once it has been decided that a person is fit to plead, there is still the question whether at the time of the alleged act D was a sufficiently responsible moral agent: the defence of insanity 
addresses this issue. Before, that, however, a few words must be said about young children ${ }^{43}$.

The infancy defense, which dates back to the common law and is still recognized in some form or another in the vast majority of jurisdictions, bars the prosecution of children below a specified age (age seven at common law) and presumptively precludes prosecution of older minors (ages seven to fourteen at common law) in the adult criminal justice system (although, under modern statutes, children in the latter group are still eligible for prosecution in juvenile delinquency proceedings) 44 .

At common law, children below the age of seven were historically deemed doli incapax-irrebuttably presumed to be incapable of forming criminal intent and therefore immune from prosecution for a crime. Children between the ages of seven and fourteen were presumptively doli incapax but that presumption could be rebutted by "very strong and pregnant evidence" by the state that the child had the "discretion to judge between good and evil" and "understood what he did". According to William Blackstone, the infancy defense reflected both a judgment about the impropriety of exacting punishment upon those who were not responsible for their actions and the practical consideration that categorically immunizing all children from prosecution could "propagat[e] a notion that children might commit ... atrocious crimes with impunity". The infancy defense was carried over into the criminal law of the United States along with other traditional concepts of English law, and it shaped the course of early prosecutions of children. Several states codified the doctrine in their penal codes. The chronological distinctions drawn by the infancy defense comport (albeit, not neatly) with classic social scientific theories about child development and maturation, particularly the works of Anna Freud and Erik Erikson on children's mental functioning and the works of Jean Piaget and Lawrence Kohlberg on children's moral growth. Current psychological research on children's maturity and mental capacity supports the view that "decision-making capacities increase through childhood into adolescence and that, although there is great

\footnotetext{
43 Andrew Ashworth. Principles of Criminal Law // https://books.google.com.ua/ books?id=pZkDDAAAQBAJ\&pg=PA157\&lpg=PA157\&dq

${ }^{44}$ Randy Hertz. Encyclopedia of Crime and Justice // http://www.encyclopedia.com/law/legal-and-political-magazines/excuse-infancy
} 
variability among individuals, preadolescents and younger teens differ substantially from adults in their abilities" 45 .

The infancy defense has been largely superseded by the establishment of a dual adult/juvenile justice system in which (1) the juvenile court has jurisdiction over prosecutions of children below a certain age (usually set at ages sixteen, seventeen, or eighteen), although typically "waiver" or "transfer" statutes provide for adult criminal prosecution of children at the upper end of the juvenile court's age bracket if they are charged with enumerated serious crimes; and (2) in some states, a juvenile court statute or case law categorically bars the prosecution of very young children (usually following the common law in designating the age at seven, although some states set the minimum age at ten). Adult penal code statutes in some states explicitly refer to the infancy defense in denominating children who fall within the juvenile court's jurisdiction as ineligible for adult court prosecution unless the state shows at a waiver or transfer hearing that the child should be deemed criminally responsible for his or her acts.

In essence, the foregoing structure tracks the original contours of the infancy defense by immunizing very young children from prosecution and by treating most older minors as presumptively ineligible for adult criminal prosecution.

What this approach leaves uncertain, however, is what, if any, role the infancy defense should play in juvenile delinquency cases. Most of the state courts that have addressed the issue have declared that the infancy defense is inapplicable to juvenile court prosecutions because it was intended to guard children from the harshness of the adult penal system and therefore has no relevance to a rehabilitation-oriented juvenile court system ${ }^{46}$.

Some courts, however, have relied upon the common law doctrine to construe the applicable statutes as prohibiting prosecution of young children who lack the capacity to appreciate the wrongfulness of their actions or to form the mental element of the charged offense.

The infancy defense and concepts akin to it are likely to play an increasingly important role in both adult and juvenile court in the coming years. In the 1980 s and 1990 s, due at least in part to high-profile cases of youth violence and politicians' calls for

\footnotetext{
45 Randy Hertz. Encyclopedia of Crime and Justice // http://www.encyclopedia.com/ law/legal-and-political-magazines/excuse-infancy 46 Ibid.
} 
aggressive responses, there have been significant increases in the number of children transferred to adult court for prosecution and there appear to be increases in the number of juvenile court prosecutions of very young children. At the same time, emerging psychological data are raising significant questions about the capacity of even older adolescents to make competent waivers of rights and other judgments expected of criminal defendants. As a result, there may be greater attention paid to existing infancy defense statutes that apply to adult criminal prosecutions and further litigation on the applicability of the defense to juvenile court. Moreover, a social scientist has suggested that the data available thus far calls for the adoption of a new standard of "adjudicative competence," which would prohibit adult court prosecutions of adolescents who are less capable than adults to understand the nature of the proceedings and to participate meaningfully in their own defense.

Although the infancy defense is framed in a way that makes it relevant solely at the guilt innocence stage of a criminal trial, the doctrine's underlying rationale also supports the treatment of the young age of the offender as a factor that should mitigate punishment. Indeed, this reasoning is necessarily implicit in the case law deeming the defense to be inapplicable to a juvenile court system that is designed to rehabilitate, not punish, offenders. The criminal justice system has, in various ways, recognized that youth is relevant to mitigation of punishment (e.g., in death penalty statutes and sentencing guidelines that treat youth as a mitigating factor and in judges' sentencing decisions in individual cases) but the legislatures and courts thus far have not adopted a categorical approach to the subject of youth at sentencing. Indeed, the Supreme Court of the USA has held that the Eighth Amendment's cruel and unusual punishment clause does not bar execution of children who were at least sixteen at the time of the crime (Stanford $v$. Kentucky, 492 U.S. 361 (1989)) even though several states' statutes and international conventions prohibit the execution of individuals who were under the age of eighteen at the time of the crime ${ }^{47}$.

In England and Wales the minimum age of criminal responsibility is 10 , substantially lower than the minimum age in many other European countries, where teenage children are dealt with in civil tribunals up to the age of 14,16 , or even 18 .

\footnotetext{
47 Randy Hertz. Encyclopedia of Crime and Justice // http://www.encyclopedia.com/ law/legal-and-political-magazines/excuse-infancy
} 
At common law the presumption of doli incapax applied to children under 14, requiring the prosecution to establish that the child knew that the behaviour was seriously wrong before the case could go ahead ${ }^{48}$. The presumption was much criticized, particularly in a social context where young offenders were often demonized by the press and politicians, and it was abolished by $\mathrm{s}$ 34 of the Crime and Disorder Act 1998. However, it remains important to think about fundamental issues in relation to the responsibility of young offenders. Are they fit to stand trial at the age of 10? Do they have sufficient understanding of the proceedings to participate meaningfully in them? In what sense are they responsible citizens at that age? Can it be said that, when they do criminal things with the required fault element, they are acting as moral agents, in a sufficiently full sense? The first two points were discussed by the European Court of Human Rights in $V$ and $T v$ United Kingdom (1999), drawing on the International Convention on the Rights of the Child, which does not lay down a minimum age of criminal responsibility but does declare several other relevant standards ${ }^{49}$. The Court held that, although the trial process to which the two 11-year-old applicants were subjected did not amount to 'inhuman and degrading treatment' within Article 3 of the Convention, the trial did violate Article 6 in its failure to ensure that the boys understood the proceedings and had the opportunity to participate, and in the failure to reduce feelings of intimidation and inhibition. A subsequent Practice Direction sets out the steps that trial judges should take in these unusual cases in order to comply with Article 6, but the Strasbourg Court has now held that this gives insufficient priority to the need to ensure that all young children have adequate opportunity to participate meaningfully in the criminal trial. Moreover, the European Commissioner on Human Rights has specifically recommended that consideration be given to raising the age of criminal responsibility 'in line with norms prevailing across Europe', on the grounds that children of 10,11 or 12 cannot have sufficient consciousness of the nature and consequences of their actions ${ }^{50}$.

In Ukraine, a person incurs criminal liability when they reach the age of 16 (general age). In certain cases some 14 year-olds

\footnotetext{
48 Andrew Ashworth. Principles of Criminal Law // https://books.google.com.ua/ books?id=pZkDDAAAQBAJ\&pg=PA157\&lpg=PA157\&dq

49 Ibid.

50 Andrew Ashworth. Principles of Criminal Law // https://books.google.com.ua/ books?id=pZkDDAAAQBAJ\&pg=PA158\&lpg=PA158\&dq
} 
can be brought before court (reduced age) for some crimes. The socially harmful danger of such crimes can be appreciated by a teenager in an earlier age. These are: premeditated murder, infringement on life of a public or governmental figure, a prosecutor, the man of law, the member of the public formation who is in charge for public order and the state boundary or military man, intentional personal injury which caused the health breakdown, mugging, act of terrorism, hostage taking, rape, theft/larceny, burglary, robbery, ruffianism, intentional damage of property, damage to means of communication, vehicles and other offences, listed in Article 22 of the Criminal Code of Ukraine. Ukrainian legislator also distinguishes the reduced age of criminal liability. For example, criminal liability incurs from the age of 18 for involving the juveniles into criminal activities (Art. 304 of the Criminal Code of Ukraine) for the crimes against the order of performing the military service. The person is considered to be the one who reached a certain age not on the day of his birthday, but 24 hours after his birthday.

Insanity. The person is pleaded as criminally sane, if he could be aware of his actions and control them while committing a crime. A person who suffers from a severe cognitive or volitional disorder, i.e., a disorder that undermines the actor's ability to perceive reality (cognition) or to control her conduct (volition), is undeterrable by the threat of punishment. Therefore, punishment is inefficacious.

The insanity defense distinguishes the mad from the bad; it separates those whom we consider evil from those whom we consider sick. A person is not a moral agent, and thus is not fairly subject to moral condemnation, if she lacked the capacity to make a rational choice to violate the law or if she lacks the capacity to control her conduct.

Insanity is characterized by two criteria: the medical one (presence of the mental disease) and the juridical one (inability of a person to be aware of his actions and to control them while committing a crime). The medical criteria of insanity may be one of the four types of mental disorder: a chronic mental disease, a temporal mental disease, weak-mindedness or another unhealthy state of mind. The juridical (psychological) criterion of insanity is characterized by the intellectual volitional aspects. The intellectual aspect means the absence of the person's ability to be aware of his actions. The volitional aspect means the person's inability to control his actions. In order to plead the presence of juridical criteria it is enough to determine either the intellectual or the volitional 
criterion. In order to plead the person insane it is necessary to determine both the medical and juridical criteria. Certain enforcement measures of the medical character may be applied to the insane. If the person was pleaded to be insane at the moment of committing a crime, he doesn't bear the criminal liability.

The insanity defense distinguishes the mad from the bad; it separates those whom we consider evil from those whom we consider sick. A person is not a moral agent, and thus is not fairly subject to moral condemnation, if she lacked the capacity to make a rational choice to violate the law or if she lacks the capacity to control her conduct.

The M'Naghten Test of Insanity states that a person is legally insane if, at the time of the act, he was laboring under such a defect of reason, from disease of the mind, as: (1) not to know the nature and quality of the act he was doing; or, (2), if he did know it, that he did not know what he was doing was wrong. Although the M'Naghten test originally was phrased in terms of whether the defendant "knew" the nature and quality of his action or "knew" right from wrong, many jurisdictions now use the word "appreciate." "Appreciate" is a word intended to convey a deeper, or broader, sense of understanding than simple "knowledge." 51

Courts have split fairly evenly on whether "Right/Wrong" prong refers to legal or moral wrongfulness. In jurisdictions that use the "moral wrong" test, the relevant issue is not whether the defendant believed that his act was morally right, but rather whether he knew (or appreciated) that society considered his actions morally wrong 52 .

The "irresistible impulse" ("control") test of insanity provides that a person is insane if, as the result of mental illness or defect, she "acted with an irresistible and uncontrollable impulse," or if she "lost the power to choose between ... right and wrong, and to avoid doing the act in question, as that [her] free agency was at the time destroyed."

The "product" (Durham) test of insanity provides that a person is excused if his unlawful act was the product of a mental disease or defect. As subsequently defined, "mental disease or defect" is "any abnormal condition of the mind which substantially affects mental or emotional processes and substantially impairs behavior controls."

51 Joshua Dressler. Black Letter Outline on Criminal Law // https:// books.google.com.ua/books?id=HFzaCgAAQBAJ\&pg=PT118\&lpg=PT118\&dq 52 Ibid. 
Thus, to be acquitted according to this rule, two matters must be proved: the defendant suffered from a mental disease or defect at the time of the crime; and, but for the mental disease or defect, he would not have committed the crime ${ }^{53}$.

The MPC test represents a broadened version of the M'Naghten and irresistible impulse tests. With modifications, it retains the second prong of M'Naghten and adds to it a volitional prong. The Code provides that a person is not responsible for her conduct if, at the time of the criminal act, as the result of a mental disease or defect (a term left undefined), she lacked the substantial capacity either: (1) to appreciate the criminality (or, in the alternative, wrongfulness) of her actions; or (2) to conform her conduct to the dictates of the law. Both MPC prongs are modified by the phrase "lacks substantial capacity." Total cognitive or volitional incapacity is not required.

First, the Code uses the word "appreciate" rather than M'Naghten's "know," to permit a deeper, fuller analysis of the individual's cognitive capacity. Second, the drafters chose not to decide between "legal wrong" and "moral wrong": they invited legislators, in adopting the Code provision, to choose between the words "criminality" (legal wrong) and "wrongfulness" (moral wrong).

Volitional prong is phrased to avoid the undesirable or potentially misleading words "irresistible" and "impulse." A person who has a very strong, but not irresistible, desire to commit a crime, including one who acts non-impulsively after considerable thought, can fall within the language of the MPC ${ }^{54}$.

Diminished sanity is characterized by two criteria: the medical one and the juridical one. The medical one is the presence of the mental disease, and juridical one is expressed by two features: inability to be fully aware his actions (the intellectual criterion), and inability to fully control his actions (the volitional criterion).

A defendant may potentially raise a claim of "diminished capacity" in order to show that he lacked the requisite mens rea for an offense. In that manner, "diminished capacity" works like mistake-of-fact or voluntary intoxication-it does not excuse the wrongdoer, but serves to show that the prosecutor has failed to prove an essential element of an offense ${ }^{55}$.

53 Joshua Dressler.
https://books.google.com.ua/books?id=HFzaCgAAQBAJ\&pg=PT119\&lpg=PT119\&dq
54 Joshua Dressler. Black Letter Outline on
https://books.google.com.ua/books?id=HFzaCgAAQBAJ\&pg=PT120\&lpg=PT120\&dq.
55 Joshua Dressler. Black Letter Outline on Criminal Law //
https://books.google.com.ua/books?id=HFzaCgAAQBAJ\&pg=PT121\&lpg=PT121\&dq 
"Diminished capacity" may also serve as a highly controversial excuse defense, used exclusively in criminal homicide prosecutions, as a basis for reducing the severity of the offense.

A sane person may suffer from a mental disability (e.g., mental illness, mental retardation, Alzheimer's) that arguably prevents him from forming the mental state required for the commission of an offense.

As a matter of logic, a defendant should be acquitted of any offense for which he lacked the requisite mens rea, including those cases in which he lacked the mental state because of a mental disability, whether that disability is permanent or temporary. This is the position taken by the Model Penal Code.

Logic notwithstanding, most states permit evidence of an abnormal mental condition, if at all, in order to negate the specific intent in a specific-intent offense. Psychiatric evidence is inadmissible in the prosecution of general-intent offenses. A minority of jurisdictions do not permit diminished capacity to be claimed in any case.

In the USA, the partial defense was originated in California and adopted by a small number of other courts. This rule, no longer followed in California, provides that a person who commits a criminal homicide and suffers from some mental illness or abnormality short of insanity may have her offense reduced because of her diminished mental capacity. States that recognize the partialresponsibility claim permit reduction of the offense from first-degree to second-degree murder, or from murder to manslaughter. The underlying rationale of the partial responsibility doctrine is that a person who does not meet a jurisdiction's definition of insanity, but who suffers from a mental abnormality, is less deserving of punishment than a killer who acts with a normal state of mind. Therefore, she should be convicted of a lesser offense.

The MPC provides that a homicide that would otherwise be murder is reduced to manslaughter if the homicide was the result of "extreme mental or emotional disturbance for which there is a reasonable explanation or excuse." This language is intended to permit courts to recognize a partial responsibility defense ${ }^{56}$.

56 Joshua Dressler. Black Letter Outline on Criminal Law // https: / / www.google.com.ua/search?biw=944\&bih=968\&ei=z541Ws77AoWBacKYp YgO\&q 


\section{MENS REA - POSITIVE AND NEGATIVE FAULT REQUIREMENTS}

The concept of mens rea (a phrase meaning evil or bad mind) is a well-developed concept, and perhaps the most complex and confusing concept in criminal law. Several problems contribute to this complexity. States are free to establish their own precedent which results in disparate requirements of intent for similar crimes, there are distinctly different common law and US Model Penal Code (MPC) definitions of mens rea, the notion of blameworthiness is not precisely attached to certain types of mens rea and indeed may be more useful in defenses to crime, and finally, to successfully prosecute a case, a different type of mens rea may be needed to help establish the actus reus, concurrence, or other circumstance element stated in the criminal statute ${ }^{57}$.

The term "mens rea" has both a broad and a narrow meaning. In the broad sense of the term, a person has acted with mens rea if they committed the actus reus of an offense with a "vicious will," "evil mind," or "morally blameworthy" or "culpable" state of mind58.

Mens rea exists in the narrow, or "elemental" sense of the term if, but only if, a person commits the actus reus of an offense with the particular mental state set out expressly in the definition of that offense. This may be called the "elemental" definition of mens rea.

It is frequently asserted that a person who commits the actus reus of an offense without a mens rea is not dangerous, could not have been deterred, and is not in need of reform. Therefore, her punishment would be counter-utilitarian. Also, the mens rea requirement is solidly supported by the retributive principle of just deserts. A person who commits the actus reus of an offense in a morally innocent manner, i.e., accidentally, does not deserve to be punished, as she did not choose to act unlawfully.

The best way to understand mens rea (often mislabeled intent) is to realize that it is always invisible. You can't really prove intent like you can with motive. You also can't really blame someone for their motive (it's understandable), only for their

57 Criminal Law // http://tafarim.blogspot.com/2010/12/criminal-lawignorance-of-law-is-no.html

58 Joshua Dressler. Black Letter Outline on Criminal Law // https://books.google.com.ua/books?id=HFzaCgAAQBAJ\&pg=PT227\&lpg=PT227\&dq 
intent. Intent is different for every person and for every case, and it's impossible as well as futile to get inside the "mind" of each and every criminal offender. Confessions are the closest thing to direct evidence of mens rea, and even then, they must be corroborated. Therefore, the criminal law has established certain objective tests for inferring the subjective mental state (intent) of criminal offenders. To do this requires certain assumptions about responsibility, and by adding in the rules for inferring intent, called determining culpability, we arrive at a way to attach blameworthiness ${ }^{59}$.

Let's take the assumptions about responsibility first. It's easy. This is a given in criminal law. The entire criminal justice system operates on the assumption of free will. Much to the chagrin of psychologists, sociologists, and sociobiologists who have argued for years that human behavior is determined by forces beyond individual control, the criminal justice system assumes that every human being possesses free will and makes choices that they must be responsible for. Notice I didn't say "accountable for" because we haven't yet reached the point where we can attach blame. The free will assumption has been called the theoretical underpinning of criminal law. It's important to understand the theory before making any assessment of it 60 .

Without getting into philosophical notions of Justice, there are two down-to-earth reasons for the free will assumption. One is that the system could not operate efficiently if we took the time to closely examine the psychological makeup of each and every individual. The second reason is that there is a whole other side to the justice system, called defenses, which offer more than enough safeguards, along with things like the presumption of innocence until proven guilty, to justify an assumption that crime is always a behavior that is freely chosen. Now all this doesn't mean that judges and lawyers don't believe in the influence of genetic, psychological, or environmental influences on human behavior. It just means that, for purposes of having a workable operating assumption, we have carved out criminal behavior from the dimension of all human behavior and decreed

\footnotetext{
59 Joshua Dressler. Black Letter Outline on Criminal Law // https: / / books.google.com.ua/books?id=HFzaCgAAQBAJ\&pg=PT228\&dq 60 Dr. Gorakhnath Munde. Forensic Medicine, Toxicology and Forensic Science // http://gorakhnathmunde.blogspot.com/2012/12/forensic-medicine-toxicologyand.html
} 
that this thing we call crime shall be considered as freely chosen from now on.

Traditionally, this stance has been softened somewhat by mutually agreed-upon recognitions. Notice we didn't say "exceptions." There are no exceptions to the free will assumption. However, there are the "Three I's" of Insanity, Infancy, and Involuntary. The criminal law "recognizes" to varying degrees that insane people, extremely young people, and those with certain involuntary "medical" conditions should not be assumed to be responsible for their actions. These are best understood as special defenses that get to the idea of voluntariness of acts, or volition (the ability to exercise free will). Insanity and infancy are fairly selfexplanatory, but the following is a list of involuntary "medical" conditions: reflexive behavior, unconscious behavior, behavior while asleep (sleepwalking), convulsive behavior (epilepsy), and involuntary intoxication (drugged against your will) ${ }^{61}$.

Now we're ready to take up the notion of culpability (faulting or blaming someone for the way their "mind" works). That definition should stop and give you pause as to what precarious ground we're on with concepts like mental fault. Let's start with the common law approaches. Most lawyers are trained in the common law approach because the MPC method is fairly recent and hasn't caught on as much as it should ${ }^{62}$.

At common law, a person commits the social harm of an offense "intentionally" if: (1) it was her conscious object to cause the result; or (2) if she knew that the result was virtually certain to occur because of her conduct.

Courts frequently speak of a "transferred intent" doctrine: A person acts "intentionally" as the term is defined above, if the result of her conduct differs from that which she desired only in respect to the identity of the victim.

Some offenses require proof that the actor had knowledge of an attendant circumstance. At common law, a person acts "knowingly" regarding an existing fact (an "attendant circumstance") if she either: (1) is aware of the fact; (2) correctly believes that the fact exists; or (3) suspects that the fact exists

\footnotetext{
${ }^{61}$ Dr. Gorakhnath Munde. Forensic Medicine, Toxicology and Forensic Science // http://gorakhnathmunde.blogspot.com/2012/12/forensic-medicine-toxicologyand.html

62 Kenya Criminal Law: The Fundamentals // http://kenyalawsonline.blogspot.com/ 2013/06/kenya-criminal-law-fundamentals.html
} 
and purposely avoids learning if her suspicion is correct. The latter form of "knowledge" is sometimes called "willful blindness."

Risk-taking is properly divisible into various types: justifiable risktaking; unjustifiable risk-taking that may properly result in tort damages; and unjustifiable risk-taking that may also result in criminal punishment. The latter forms of risk-taking are frequently described as "negligent" risk-taking and "reckless" risk-taking63.

In order to determine whether risk-taking is justifiable or not, one must look at three factors: the gravity of harm that a reasonable person would foresee might occur as the result of the risk-taking conduct; the probability that this harm will occur; and the reason for the proposed conduct, i.e., the benefit to the individual or society of taking the risk. A risk is unjustifiable if the gravity of the foreseeable harm, multiplied by the probability of its occurrence, outweighs the foreseeable benefit from the conduct 64 .

A person acts in a "criminally negligent" manner if she should be aware that her conduct creates a substantial and unjustifiable risk of social harm. Synonyms for "criminal negligence," include "gross negligence" and "culpable negligence."

Oliver Wendell Holmes, Jr., believed that a person acts "recklessly" if she should be aware that she is taking a very substantial and unjustifiable risk. This is simply a heightened version of "criminal negligence." Notice: "civil negligence" involves unjustifiable risktaking; "criminal negligence" is substantial and unjustifiable risk-taking; and "recklessness" (as defined here) is very substantial and unjustifiable risk-taking.

Most courts now provide that a person acts "recklessly" if she consciously disregards a substantial and unjustifiable risk that her conduct will cause the social harm of the offense. Under this definition, "recklessness" differs from "criminal negligence" in that it requires that the actor subjectively be aware of the substantial and unjustifiable risk.

A person acts with "malice" if she intentionally or recklessly causes the social harm of an offense, as the latter mens rea terms are defined above ${ }^{65}$.

63 Joshua Dressler. Black Letter Outline on Criminal Law // https: / / books.google.com.ua/books?id=HFzaCgAAQBAJ\&pg=PT228\&dq 64 Joshua Dressler. Black Letter Outline on Criminal Law // https:// books.google.com.ua/books?id=HFzaCgAAQBAJ\&pg=PT233\&lpg=PT233\&dq. 65 Joshua Dressler. Black Letter Outline on Criminal Law // https://books.google.com.ua/books?id=HFzaCgAAQBAJ\&pg=PT236\&lpg=PT236\&dq 
The common law distinguishes between "general intent" and "specific intent" crimes. The distinction is critical, because some defences apply only, or more broadly, in the case of socalled "specific intent" offenses. In most cases, a "specific intent" offense is one that explicitly contains one of the following mens rea elements in its definition: (1) the intent to commit some act over and beyond the actus reus of the offense; (2) a special motive for committing the actus reus of the offense; or (3) awareness of a particular attendant circumstance 66.

Any offense that requires proof of a culpable mental state, but which does not contain a specific intent, is a "general intent" offense. Sometimes, such an offense will have no explicit mens rea term in the definition of the offense; it is enough that the defendant committed the actus reus with any culpable state of mind.

A frequent issue in criminal law litigation is whether a mens rea term in the definition of an offense applies to all or only some of the actus reus elements in the definition of the crime. In the absence of explicit rules, courts have struggled to interpret modern statutes.

The ultimate issue for any court today-always-is to determine what the legislature intended. A court will try to resolve interpretive problems by ascertaining the intention of the drafters of the law, sometimes by looking through legislative history. Often, however, evidence regarding legislative intent is nonexistent or ambiguous, so courts must look elsewhere.

Courts often look at the placement of the mens rea term in the definition of the offense, in order to ascertain legislative intent. See the Main Outline for a useful example.

Courts sometimes assume that, absent evidence to the contrary, mens rea terms in the definitions of offenses do not apply to "attendant circumstance" elements of the crime ${ }^{67}$.

An offense is "strict liability" in nature if commission of the actus reus of the offense, without proof of a mens rea, is sufficient to convict the actor. Strict liability most often applies in relation to "public welfare" offenses. Such offenses typically involve malum prohibitum conduct, i.e., conduct that is wrongful only because it is prohibited (e.g., motor vehicle laws), as distinguished from malum in se conduct, i.e., inherently wrongful conduct (e.g., murder) ${ }^{68}$.

\footnotetext{
66 Joshua Dressler. Criminal Law // http://euro.ecom.cmu.edu/ program/law/08-732/Types / DresslerCriminal.pdf

67 Joshua Dressler. Black Letter Outline on Criminal Law // https: / / books.google.com.ua/books?id=HFzaCgAAQBAJ\&pg=PT80\&lpg=PT80\&dq 68 Joshua Dressler. Criminal Law // http://euro.ecom.cmu.edu/ program/law/08-732/Types/DresslerCriminal.pdf
} 
The penalty for violation of a public welfare offense is usually minor, such as a monetary fine or a very short jail sentence. A single violation of a public welfare offense often threatens the safety of many persons, e.g., transportation of explosives on a highway not designated for such use. On rare occasion, non-public welfare offenses are considered strict liability in nature. Statutory rape is the most common example of such an offense. Strict-liability offenses are not per se unconstitutional. Nonetheless, there is a strong resumption against strict liability as to offenses that have their roots in the common law. In such circumstances, a court will not assume (absent evidence to the contrary) that the legislature intended to abandon the common law mens rea requirement, even if the statute is silent regarding this element.

Mistake of fact. A defendant is not guilty of a specific-intent crime if her mistake of fact negates the specific-intent element of the offense. Even an unreasonable mistake of fact-a mistake that a reasonable person would not make-may exculpate the actor, assuming the mistake negatives the mens rea required for the offense.

A defendant is not guilty of a general-intent offense if her mistake of fact was reasonable. An unreasonable mistake of fact does not exculpate.

Although the principle stated above is the general rule, on rare occasion a court will convict a defendant of an offense, although her mistake of fact was reasonable, if her conduct violates the "moral wrong" doctrine. This doctrine provides that there should be no exculpation for a mistake where, if the facts had been as the actor believed them to be, her conduct would be immoral, albeit legal. By knowingly committing a morally wrong act, an actor assumes the risk that the facts are not as she believed them to be, i.e., that her actions are not just morally wrong, but also legally wrong69.

Occasionally, a court will convict a defendant of an offense, although her mistake of fact was reasonable, if her conduct violates the "legal wrong" doctrine. This rule substitutes the word "illegal" for "immoral" in the description of the moral-wrong doctrine, but is otherwise applied in the same manner. Thus, a person is guilty of criminal offense $\mathrm{X}$, despite a reasonable mistake of fact, if she would be guilty of a different, albeit lesser, crime $\mathrm{Y}$, if the factual situation were as she supposed.

69 Joshua Dressler. Black Letter Outline on Criminal Law // https:// books.google.com.ua/books?id=HFzaCgAAQBAJ\&pg=PT85\&lpg=PT85\&dq 
A mistake of fact, whether reasonable or unreasonable, is never a defense to a strict-liability offense. This rule is logical: a strict-liability offense is one that requires no proof of mens rea. Therefore, there is no mens rea to negate. A defendant's mistake of fact is legally irrelevant ${ }^{70}$.

Let's take a look at the common law approaches in tabular form.

\begin{tabular}{|l|l|}
\hline General & $\begin{array}{l}\text { The kind of intent which a judge or jury can } \\
\text { easily infer or presume from the act itself. The } \\
\text { intended result doesn't matter. The prosecution } \\
\text { need not establish why the crime occured. It must } \\
\text { be shown, however, that the defendant had an } \\
\text { "awareness" of a criminal act being committed. } \\
\text { Battery is a good example because the extent of } \\
\text { injuries or why the fight started doesn't matter. }\end{array}$ \\
\hline \begin{tabular}{l|l|} 
Specific \\
intent
\end{tabular} & $\begin{array}{l}\text { The kind of intent that legislatures have put in } \\
\text { the language of the criminal statute. Usually } \\
\text { requires a particular result beyond the act itself, } \\
\text { such as "with purpose to defraud an insurance } \\
\text { company" in the crime of arson for profit. } \\
\text { Requires prosecution to prove additional elements } \\
\text { and cannot be presumed by a judge or jury. }\end{array}$ \\
\hline Strict & $\begin{array}{l}\text { Involves regulatory crimes where intent doesn't } \\
\text { matter at all. Intent is not an element of the } \\
\text { crime. It is immaterial whether the accused acted } \\
\text { in good faith or knew they were violating the law. } \\
\text { The prosecution doesn't have to prove the } \\
\text { defendant knew their mail order package } \\
\text { contained drugs or child pornography, for } \\
\text { example. }\end{array}$ \\
\hline intent & $\begin{array}{l}\text { Involves cases where the accused intended to } \\
\text { harm one victim but instead harmed another. } \\
\text { Relieves prosecution of the need to prove chain of } \\
\text { events leading to harm. Basis of felony-murder } \\
\text { rule. }\end{array}$ \\
\hline Transferred \\
\hline intent
\end{tabular}

70 Joshua Dressler. Black Letter Outline on Criminal Law // https://books.google.com.ua/books?id=HFzaCgAAQBAJ\&pg=PT86\&lpg=PT86\&dq 


\begin{tabular}{|l|l|}
\hline $\begin{array}{l}\text { Constructive } \\
\text { intent }\end{array}$ & $\begin{array}{l}\text { Involves cases where the accused should have } \\
\text { known their behavior created a high or } \\
\text { unreasonable risk of injury. Also called criminal } \\
\text { negligence, and replaces any specific intent } \\
\text { contained in statute, thereby constructing or } \\
\text { converting an innocent act to a crime. }\end{array}$ \\
\hline Scienter & $\begin{array}{l}\text { A requirement in some statutes that the accused } \\
\text { had some additional degree of knowledge beyond } \\
\text { knowing a possible criminal act was being } \\
\text { commiting. Examples include knowing that the } \\
\text { victim is a law enforcement officer, knowing that } \\
\text { the materials were stolen property, or knowing } \\
\text { that the hitchhiker was an escaped fugitive. }\end{array}$ \\
\hline
\end{tabular}

As you can see, at common law basic distinctions are made between at least six (6) different types of intent: General Intent, Specific Intent, Strict Liability, Transferred Liability, Constructive Liability, and Scienter. All crimes contain general intent, but some crimes only contain specific intent or involve other forms of intent ${ }^{71}$.

Somewhat simpler and easier-to-understand is the MPC approach. Not all states use these words, and where known, I've worked the synonymous word into the definition and indicated it by quotation marks. They are arranged from the highest degree of mental fault to the lowest.

\begin{tabular}{|l|l|}
\hline Purposely & $\begin{array}{l}\text { When a person's conscious objective is to engage in } \\
\text { a particular act or accomplish a particular result. } \\
\text { They are behaving "intentionally" with respect to the } \\
\text { attendant circumstances they are aware of or believe } \\
\text { to exist at the time. Requires prosecution to show } \\
\text { what was going thru the accused's mind at the time. }\end{array}$ \\
\hline \hline Knowingly & $\begin{array}{l}\text { When a person knows the nature of their conduct } \\
\text { will necessarily lead to a particular result. It means } \\
\text { "willfully" carrying out a design or plan as a } \\
\text { conscious exercise of their will. Requires } \\
\text { prosecution to show what was going thru the } \\
\text { accused's mind at the time. }\end{array}$ \\
\hline
\end{tabular}

${ }^{71}$ Criminal Law // http://tafarim.blogspot.com/2010/12/criminal-lawignorance-of-law-is-no.html 


\begin{tabular}{|l|l|}
\hline Recklessly & $\begin{array}{l}\text { When a person consciously disregards a substantial } \\
\text { and unjustifiable risk that grossly deviates from a } \\
\text { standard of care that a reasonable person would } \\
\text { follow under the circumstances. Requires } \\
\text { prosecution to show what was going thru the } \\
\text { accused's mind at the time AND show what a } \\
\text { reasonable person would do under the } \\
\text { circumstances. }\end{array}$ \\
\hline Negligently \\
$\qquad \begin{array}{l}\text { When a person fails to be aware of a substantial } \\
\text { and unjustifiable risk that dangerous } \\
\text { circumstances exist or a prohibited result will } \\
\text { follow. Such failure is also a substantial deviation } \\
\text { from the standard of care that a reasonable person } \\
\text { would follow under the circumstances. Requires } \\
\text { prosecution to show what a reasonable person } \\
\text { would do under the circumstances }\end{array}$ \\
\hline
\end{tabular}

According to Section 2.02, Subsection 1 of the MPC, "a person is not guilty of an offense unless he acted purposely, knowingly, recklessly, or negligently, as the law may require, with respect to each material element of the offense."73

In general, the MPC requires proof of mens rea. More significantly, it requires proof of some particular mens reapurpose, knowledge, recklessness, or negligence-as to each material element of the offense. This contrasts with the common law, where there might be a mens rea requirement as to one element but no mens rea required as to other elements. In other words, with the MPC, each actus reus element should be "covered" by some mens rea requirement.

The common law term "intentionally" is not used in the Model Penal Code. Instead, the MPC subdivides "intent" into its two alternative components, and calls them "purposely" and "knowingly." A person causes a result "purposely" if it is her conscious object to cause the result.

A person "knowingly" causes a result if she is aware that the result is "practically certain" to occur from her conduct. A person acts "knowingly" as to an attendant circumstance if he is aware

\footnotetext{
${ }^{72}$ Criminal Law // http://tafarim.blogspot.com/2010/12/criminal-lawignorance-of-law-is-no.html

73 Model Penal Code - Selected Provisions // http://www1.law.umkc.edu/ suni/crimLaw/MPC_Provisions/model_penal_code_default_rules.htm
} 
that the circumstance exists, or if he is aware "of a high probability of its existence, unless he actually believes that it does not exist." The latter provision is the Code version of the "wilful blindness" doctrine.

A person is said to have acted recklessly if "he consciously disregards a substantial and unjustifiable risk that the material element exists or will result from his conduct. The Code provides, basically, that the standard of measuring the gravity of foreseeable harm, the probability of its occurrence, and the reasons for taking the risk should be applied ${ }^{74}$.

One is reckless when the risk-taking "involves a gross deviation from the standard of care that a reasonable person would observe in the actor's situation." A person acts negligently when he should be aware of a "substantial and unjustifiable risk." This is a risk that constitutes "a gross deviation from the standard of care that a reasonable person would observe in the actor's situation." The critical difference between recklessness and negligence under the Code is that in the former case, the actor is consciously aware of the substantial and unjustifiable risk, but proceeds anyway; in the case of negligence, the actor is not aware of the risk, but should be.

The MPC requires some mens rea term for each element of an offense ( $\S 2.05$ aside). If the statute defining an offense is silent regarding the issue of mens rea as to one or more of the actus reus elements, the Code provides that "such element is established if a person acts purposely, knowingly, or recklessly with respect thereto." In essence, you fill in the blank with "purposely, knowingly, or recklessly."

If the definition of a MPC statute only sets out a single mens rea element in the definition of the offense, that mens rea term applies to every material element of the offense, unless a contrary legislative intent "plainly appears." 75

Subject to one exception noted below, a mistake of fact is a defense to a crime if the mistake negates a mental state element required in the definition of the offense. The Code dispenses with the common law distinction between "general intent" and "specific intent" offenses: the mistake-of-fact rule applies to all offenses in the same manner.

\footnotetext{
74 Joshua Dressler. Black Letter Outline on Criminal Law // https:// books.google.com.ua/books?id=HFzaCgAAQBAJ\&pg=PT81\&lpg=PT81\&dq 75 Joshua Dressler. Black Letter Outline on Criminal Law // https:// books.google.com.ua/books?id=HFzaCgAAQBAJ\&pg=PT83\&lpg=PT83\&dq
} 
In a variation on the common law legal-wrong doctrine, the defense of mistake-of-fact is inapplicable if the defendant would be guilty of a lesser offense had the facts been as she believed them to be. However, under such circumstances-unlike the common law-the defendant will be punished at the level of the lesser, rather than the greater, offense.

Mistake of law. In general, knowledge of the law is not an element of an offense. Moreover, a mistake of law-even a reasonable one!-does not ordinarily relieve an actor of liability for the commission of a criminal offense.

The law is definite. Therefore, any mistake of law is inherently unreasonable. If a mistake-of-law defense were recognized, it would invite fraud. Every defendant would assert ignorance or mistake, and it would be nearly impossible to disprove the claim. Also, we want people to learn the law. To promote education-to deter ignorance-the law must apply strict liability principles ${ }^{76}$.

Mistakes that negate the mens rea. A defendant is not guilty of an offense if his mistake of law, whether reasonable or unreasonable, negates an element of the crime charged. A person is not guilty of a criminal offense if, at the time of the offense, he reasonably relied on an official statement of the law, later determined to be erroneous, obtained from a person or public body with responsibility for the interpretation, administration, or enforcement of the law defining the offense.

Although the common law is less clear than the Model Penal Code in this regard, apparently a defendant may reasonably rely on an official statement of the law found in a statute, judicial opinion, administrative ruling, or an official interpretation of the law given by one who is responsible for the law's enforcement or interpretation, such as the United States or State Attorney General.

In very rare circumstances, it offends due process to punish a person for a crime of which she was unaware at the time of her conduct. The Due Process Clause apparently is violated if three factors exist: (1) the "unknown" offense criminalizes an omission; (2) the duty to act is based on a status condition rather than conduct; and (3) the offense is malum prohibitum in nature ${ }^{77}$.

\footnotetext{
76 Joshua Dressler. Black Letter Outline on Criminal Law // https: / / books.google.com.ua/books?id=HFzaCgAAQBAJ\&pg=PT87\&lpg=PT87\&dq 77 Joshua Dressler. Black Letter Outline on Criminal Law // https:// books.google.com.ua/books?id=HFzaCgAAQBAJ\&pg=PT89\&lpg=PT89\&dq
} 


\section{PLANS OF PRACTICAL TRAINING}

Theme 1. The concept, task, function, principles of criminal law. Criminal law system

1. The concept and subject of criminal law as a branch of law, academic discipline, science.

2. Tasks, functions and objectives of criminal law as a branch of law. Interconnection of these categories.

3. Principles of criminal law.

4. The criminal law system. The science of criminal law and its relation with related sciences.

\section{Theme 2. Criminal law}

1. The concept and meaning of the criminal law. Signs of the criminal law.

2. The criminal law system. General and Special Part of the Criminal Code: Their Interconnection.

3 . The concept and structure of the criminal law.

4. Concepts and types of dispositions.

5 . The concept and types of sanctions.

6. Concept and meaning of the interpretation of the criminal law.

7. Types of interpretation.

8. The legal nature of the judicial precedent in the criminal law of Ukraine.

9. Constitution and criminal law.

10. International conventions, treaties and criminal law.

11. General provisions on the validity of the criminal law in time. Principle of retroactivity in criminal law. Act of interim law in time.

12. Principles of the criminal law in space and by persons. Place of committing a crime.

13. Extradition of persons who committed a crime (extradition).

Task:

1. Write in article 4 of the General Part of the Criminal Code a summary and justify their belonging to this part of the Criminal Code. 
2. Write in the abstract 4 articles of the Special Part of the Criminal Code and substantiate their belonging to this part of the Criminal Code.

3. Find $2-3$ articles that contain several parts, write down to the abstract of the definition of the part.

4. Find and write down to the summary 4-5 criminal law that contains different types of dispositions.

5. Find and write down a summary of 4-5 criminal law that contains various types of sanctions.

6. Justify the expediency of applying the resolutions of the Plenary Session of the Supreme Court of Ukraine on the example of a specific court judgment.

7. Identify the stages of the adoption of the criminal law.

8. Make a scheme of moments of entry into force of the criminal law.

Case 1

M. attempted to kill several people. What normative-legal act protects the human right to life? Justify the answer.

Case 2

L. did an act that was criminalized a few days later. Is it possible to regard L.'s actions as criminal? Justify the answer.

Case 3

$\mathrm{N}$ heard that under the amnesty he would be released from criminal responsibility, so decided to commit a crime. And only then learned that there was no such release.

Can $\mathrm{N}$ to be considered a criminal? Justify the answer?

Case 4

K. committed theft in large numbers.

What part of art. 185 of the Criminal Code provides for his actions?

\section{Case 5}

M. committed the crime on August 30, 2001

What Code should be used in solving the issue of liability? Justify the answer.

Case 6

Judgment of the court of January 29, $2002 \mathrm{~V}$. convicted for art. 97 of the Criminal Code of 1960 for 2 years imprisonment for the fact that on August 6,2001, while in a state of intoxication, during the protection of the grain flow of a private agricultural 
trading company, he spook fully spoke on GG. Then, between him and the victim's husband G.V. arose a controversy that grew into a brawl, during which G.V. poured V. on the ground, clasped his hands around his neck and began to choke, from which he hardly fainted. Considering such actions as a real threat to his life and health, B. got out of his pocket and, wanting to get rid of the seizure and stop the encroachment of GV, he deliberately inflicted him 10 strokes with a knife in the chest and on the limbs, resulting in G. B. died.

In the appeal, the prosecutor raised the issue of changing the court's sentence and re-qualifying the actions of V. from Art. 97 of the Criminal Code of 1960 at Art. 118 of the Criminal Code of 2001.

What should the Supreme Court decide?

\section{Case 7}

The verdict of the court of April 19, 2001 X., recognized as a particularly dangerous recidivist, was convicted under Part 4 of Art. 140 of the 1960 Criminal Code for 7 years imprisonment with the confiscation of all property for the fact that on February 20, 2001, under a preliminary conspiracy with Ch., he secretly stole from Bread M. poultry for the amount of $140 \mathrm{UAH}$. The District Court decision of February 19, 2002 brought the sentence in accordance with the Criminal Code of 2001: it excluded the decision to recognize $\mathrm{X}$. as a particularly dangerous recidivist and re-qualified the actions of X. With Part 4 of Art. 140 Criminal Code of 1960 on Part 3 of Art. 185 of the Criminal Code of 2001 on the basis of the theft, which caused considerable damage to the victim, and softened the punishment to 6 years imprisonment.

The decision of the district court was filed with the submission to the Supreme Court of Ukraine, in which the issue of changing the court ruling and re-qualification of his actions with Part 3 of Part 2 of Art. 185 of the Criminal Code of 2001 and imposition of a punishment in the form of 5 years imprisonment.

What should the Supreme Court decide?

Case. 8

L. and $\mathrm{H}$. for the commission of hooliganism, connected with the resistance of the representative of state, were convicted on August 18, 2001 under Part 2 of Art. 206 of the 1960 Criminal Code in accordance with 3 years of imprisonment and up to 2 years 6 months imprisonment. They appealed to the verdict to 
reduce their punishment, which was considered in September 2001.

Compare the codes of 1960 and 2001. What is the decision to take by the court of appeal?

\section{Case 9}

D., who permanently resided in Ukraine as a stateless person, went to Greece, where he committed the robbery. Since Greece did not bring D. to criminal liability and he returned to Ukraine, the law enforcement agencies of Greece applied to Ukraine for the extradition of D.

Option: D. was a citizen of Russia.

How should you decide?

Case 10

Citizen Z. visited his relatives in Verona, where in restaurant caused a deliberate light bodily injury to a citizen of Italy. In Italy, he was not detained and returned home.

Option: Z. was a citizen of Georgia and committed a crime in Verona, after which he arrived in Ukraine.

How should the question of the responsibility of $Z$. be solved?

Case 11

N., a stateless person, went to Bulgaria for punishment for hooliganism and moved to Ukraine, where he again committed hooliganism, which was accompanied by a special insolence. Actions N. were qualified by Part 3 of Art. 296 of the Criminal Code on the basis of preliminary conviction for such a crime. $\mathrm{N}$. dismissed the verdict as inconsistent with the provisions of the Criminal Code of Ukraine on liability for a crime committed outside Ukraine, the Universal Declaration of Human Rights, the International Covenant on Civil and Political Rights.

How should you decide?

Case 12

S., who permanently lived in Kherson, traveled to Austria on his own car, where he grossly violated the rules of motor traffic safety and made a pedestrian collision, causing him deathly injuries. The Austrian court sentenced $S$. to 5 years imprisonment.

What are the legal consequences of the conviction of the Austrian court? 


\section{Case 13}

The mechanic of the enterprise of the Odessa region T., being responsible for the technical state of vehicles, has put into operation a clearly defective auto loaded with grapes. Driver S. knew about the malfunction, but went on a flight to Slovakia. Due to the failure of the steering, the driver on the outskirts of Bratislava did not manage with the controlling, resulting in an accident in which two pedestrians died.

Under the law of which state T. and S. will bear responsibility? Identify the place and time of committing crimes.

\section{Topic 3. The concept of crime and its types}

1. Formation and development of the definition of crime in the history of criminal law.

2. Concepts and features of a crime under the criminal law of Ukraine.

3. Concepts and signs of a minor act (Part 2 of Article 11 of the Criminal Code of Ukraine).

4. The concept and practical significance of the classification of crimes. Criteria and types of crime classification.

5. The difference between criminal offenses and other offenses. Question of instituting criminal offenses.

\section{Task:}

1. Fill in and write down to the summary a diagram of the signs of the crime.

2. Familiarize yourself with the Resolution of the Plenum of the Supreme Court of Ukraine of May 28, 2004 No. 9 "On Certain Issues of the Application by the Courts of Ukraine of Administrative and Criminal Legislation in Connection with the Entry into Force of the Law of Ukraine of May 22, 2003" On the Income Tax of Individuals "', Whether the said resolution retained its effect after the Tax Code of Ukraine came into force. Identify in the notebook 1) the principle of determining the nontaxable minimum used for qualifying crimes; 2) the size of the non-taxable minimum for the current year used to qualify the crimes.

3. Consider Art. 185 of the Criminal Code and Art. 51 KPAP, as well as Art. 296 of the Criminal Code and Art. 173 KPAP, compile and write down to the summary a description of the differences between the administrative offense and the crime.

4. Write down a summary in accordance with Article 3 of the Criminal Code of Ukraine, which contains: 1) crimes of minor 
importance; 2) of moderate severity; 3) grave crimes and 4) especially grave crimes.

\section{Case 1}

M., being drunk, decided to commit suicide. To achieve this, he drove an empty bus and, at a considerable speed, drove him to a thick tree. As a result, M. took a serious bodily injury, injured the bus, causing significant losses to the auto enterprise.

Take a look at the article. Articles 121, 194, 289 of the Criminal Code. Are actions of M. criminal?

Case 2

B., who served punishment for theft of someone else's property, had just been released from prison and returned home by train. At one of the stations, a woman came up with a basket of fresh cucumbers, which she had brought to the market. B. secretly stole three cucumbers. He was convicted of theft of someone else's property. B. appealed the verdict, referring to the fact that his actions only formally contain signs of theft. The Court of Appeal refused to comply with the complaint, since B. had an unpaid conviction for the same offense.

Is the court the right thing to do?

Case 3

Citizen S. was engaged in medical treatment at home without a special permission and without proper medical education. As a result of this activity, the citizen $P$. received severe drug poisoning.

Take a look at the article. $138 \mathrm{CC}$. Does the committed act have all the signs of a crime?

Case 4

The watchman G. carelessly performed his duties on the protection of the construction stock of the agricultural cooperative, while often on duty, slept, detached from the object. This was taken advantage of by $Z$., who stole building materials for a sum of 550 hryvnias.

Take a look at the article. st.185, $197 \mathrm{KK}$. Are actions of G. and $Z$. criminal?

Case 5

Mr. S. sold the computer, the money for which he promised to give in a month. However, not in a month, nor after three S. did not give money, and the computer refused to return. When $\mathrm{S}$. 
was not at home, G. secretly penetrated into his apartment and took his computer.

Take a look at the article. 185 of the Criminal Code. Are actions of $\mathrm{G}$. criminal?

\section{Case 6}

A. filed a statement to the prosecutor's office asking him to identify who his signature had been falsified in the wage bill, since he had not received money in the amount of 840 hryvnias. The investigation of the case revealed that A. deliberately distorted his signature in order to receive a salary again.

Take a look at the article. Art. 190, 358 of the Criminal Code. Are these actions are Criminal?

\section{Case 7}

$\mathrm{N}$. at night fell to another's barn and stole a farm tool with a total cost of 230 hryvnias. He was convicted of theft of someone else's property. N. appealed the verdict, insisting on closing the case due to the absence of a crime in his actions. The Court of Appeal rejected the complaint, citing the significant amount of damage caused by $\mathrm{N}$.

Option: The cost of the stolen instrument was 1,000 hryvnias.

Take a look at the article. 185 of the Criminal Code. Is N.Criminal liability subject to?

\section{Case 8}

L. after the end of the day, consuming alcoholic beverages, sat down at the wheel of the car and headed home. As a result of severe intoxication, he could not manage the car, and made a run on a citizen $\mathrm{K}$. and a citizen $\mathrm{C}$. As a result of the collision, S. was killed, and $\mathrm{K}$. was seriously injured. L. was sentenced under Part 2 of Art. 286 of the Criminal Code of Ukraine up to 8 years imprisonment with the deprivation of the right to drive a vehicle for a term of 3 years.

What kind of crime does a crime committed by L.?

Case 9

An auxiliary worker P. during his work in the food store stole 16 kilograms of flour at a cost of $70 \mathrm{UAH}$.

Does committing a crime constitute a criminal offense? Take a look at the article. 185 of the Criminal Code of Ukraine. 
Case 10

At the factory of children's toys 100 scooters were made for the price of 250 hryvnas apiece. After the goods arrived on sale, buyers were discovered a crack in the platform.

Is the factory guilty of criminal responsibility? Take a look at the article. 227 of the Criminal Code of Ukraine.

\section{Topic 4. Criminal liability and its basis}

1. The concept of criminal law relations. Object, subject, content of criminal legal relations.

2. Legal facts in criminal law.

3. Concept and forms of realization of criminal liability

4. Limits and stages of criminal liability.

5. Grounds of criminal liability.

Task:

1. In-depth analysis of the significance of the event in criminal law.

2. Make a diagram of the relationship between the stages of criminal liability and the stages of the criminal process.

Case 1

Private veterinarian was in regular military service. During the New Year holidays, he committed the abandonment of the military unit for a period of 2 days and 11 hours, for which he was prosecuted.

During the court session the defense counsel filed a motion to terminate the criminal case for the absence of the offense, as the offense committed by the offender formally contains signs of a crime provided for in Part 1 of Art. 407 of the Criminal Code, but because of its insignificance does not constitute a public danger.

Is the defense counsel justified?

Case 2

In September 2012, the artist G. made a cliché for printing money in the amount of 20 hryvnias. After that, he suggested that $Z$. produce a press for the sale of counterfeit hryvnias. He made and handed G. press. At the end of October 2012, G. at his apartment published 10 banknotes for the amount of 200 hryvnias and the next day he paid them for purchases in the store, but the cashier found that the hryvnia was fake, and G. was detained.

Take a look at the article. Art. 190, 199 of the Criminal Code. Are $\mathrm{G}$ and $\mathrm{Z}$ responsible for criminal liability? 


\section{Case 3}

$\mathrm{N}$. agreed with $\mathrm{K}$. to sell the apartment he owned for 45 thousand dollars. Since currency exchange transactions between citizens are prohibited by the current legislation, the contract of sale of the apartment indicated its cost in hryvnias, but in fact was understated 10 times in order to reduce the size of the state fee for notarization of the specified contract. In fact, for the purchased apartment K. paid N. 45 thousand dollars. State fee paid by agreement to $\mathrm{N}$.

Take a look at the article. Art. 192, 212 of the Criminal Code.

\section{Topic 5. Composition of the crime and its types}

1. The concept and meaning of the crime.

2. Functions of the crime.

3. Elements and attributes of the crime.

4. Types of crime.

5. The ratio of the concepts of crime and the composition of the crime.

Task:

1. From chapters VIII and X of the Special Part of the Criminal Code, write down to the summary alternatives to the way of the operation of the crimes.

2. Write down 3 examples of crimes with the main composition in the abstract from the Special Part of the Criminal Code of Ukraine.

3. Write down 3 examples of crimes with aggravating circumstances in the summary from the Special Part of the Criminal Code of Ukraine.

4. Write down examples of crimes with mitigating circumstances in the abstract from the Special Part of the Criminal Code of Ukraine.

5. Find and write down a summary of the Special Part of the Criminal Code of Ukraine on 3 examples of crimes with a simple composition and complicated.

6 . Find and write to the summary in 3 examples of material, formal and truncated crimes.

Case 1

K., previously convicted of theft stole from the citizen F. iron for 240 hryvnia, which was located on the balcony of her apartment. 
Signs of which deeds are qualified types of stipulated art. 185 of the Criminal Code is in the conduct of the crime?

\section{Case 2}

P. did not pay the rent for six years, owing at that time an amount exceeding 800 non-taxable minimum incomes of citizens.

Take a look at the article. Art. 192, 212 of the Criminal Code. Is the action of $\mathrm{P}$. a crime?

\section{Case 3}

S., working as the head of the capital construction department of a production association, in March 2001, used 1.43 cubic meters of masonry by misuse of his official position. timber in the value of 350 hryvnias, and in January 2002 - 150 sheets of slate worth 1,650 hryvnias.

Take a look at the article. 191 of the Criminal Code. Are S. actions criminalized?

Case 4

K., going to rest in Zatoka, asked his neighbor B. to take the most valuable things in storage for the period of her absence (videorecorder, gold jewelry, bonds, etc.). B. agreed, but later all the things that she had left for storage K. sold. When K. returned from the rest and came to $B$. to pick up her belongings, she told her that she did not take any things from her for storage. B.?

Is there evidence of a crime against property in the actions of

Case 5

A. took a refrigerator and TV set at the rental office of the limited liability company "Astra", which later sold, and drank money. Rejected rented things or paid their cost A. refused.

Read Articles 185, 190, 191 and 192 of the Criminal Code.

Are there any signs of a crime against property in A. actions?

Case 6

Candidate of medical sciences, a highly qualified surgeon I. after taking operations, took "gifts" (alcoholic beverages, money, etc.)from relatives.

Version. I. often agreed to conduct complicated operations only after receiving money from sick people or their relatives.

Are there signs of an "illegal benefit" crime in the actions of I.? 


\section{Case 7}

K., L. and S. at the apartment in the latter quarreled during the joint use of alcoholic beverages. At the same time, S. hit K. with an empty bottle on his arm, and L. - on the head.

In response, $\mathrm{K}$. and $\mathrm{L}$. began to beat $\mathrm{S}$. with their hands, legs, bottles, and stool, causing numerous damage to the internal organs, fractures of the three ribs, closed fracture of the cartilage larynx, and other injuries, which by forensic examination were recognized as grave bodily injuries. After that, K. and L. drank alcohol and went home. From the damage $S$ received, the next day he died without coming to life.

Determine the type of crime in the actions of $\mathrm{K}$. and $\mathrm{L}$.

\section{Topic 6. The object of the crime}

1. The concept and meaning of the object of the crime.

2. Types of crime objects.

3. The concept and meaning of the subject of the crime.

4. The ratio of the object and object of the crime.

5. Victim in criminal law.

\section{Task:}

1. Analyze Art. 201 of the Criminal Code of Ukraine: determine generic, species, direct (main and additional - if any) objects, subject (if specified in the article).

2. Identify generic, species, direct (basic and additional - if any) objects in articles 112, 115, 348 of the Criminal Code of Ukraine.

3. Separate the object of a criminal offense in the commission of crimes provided for in Art. 194 and Art. 352 of the Criminal Code of Ukraine.

4. Write in the abstract 4 examples of criminal law, which include the indication of the crime as a mandatory feature of the crime.

5. Write down to the summary of 3 criminal law examples that contain instructions on the behavior of the victim.

Case 1

$\mathrm{K}$. Was accused of forging money. He produced 3 money denominations, denomination of 100 hryvnias each. Bearing in mind that his acquaintance $Z$., the seller in the store, has a bad vision, $\mathrm{K}$. got him fake money for the products.

In the court session, Defender D. did not agree with the qualification of this act, arguing that the fake was so rude that it 
was not necessary to have any special studies to determine it, the more G. on the same day found that the money that he received from K., are fake and tried to return them to him. The lawyer filed a petition for a qualification as a fraud (Article 190 of the Criminal Code), and not the manufacture and sale of counterfeit money (Article 199 of the Criminal Code), since money-stamped money-stamps were not able to get in cash and could only be used for the sake of deceiving citizens.

Determine the object of the attack and explain whether the solicitor's application is to be met?

Case 2

M., working on a forklift truck, violated the safety instructions, loaded and began to carry on the territory of the furniture factory an oversized cargo, part of which fell to one of the students of the vocational school, who were at the combine on a tour, causing him severe bodily harm. Court M. was sentenced under Part 2 of Art. 286 of the Criminal Code.

Take a look at the article. Art. 271, 286 of the Criminal Code. Is the court correctly determined the object of the crime committed by M.?

\section{Case 3}

In the proceedings of the judge $\mathrm{S}$. was the case on the charge of K. in official forgery under Part 2 of Art. 366 of the Criminal Code of Ukraine. The brother of the defendant K. - V. - tried to persuade the judge to terminate the case because of the absence of the crime of the crime, offering for it a material reward. Judge $\mathrm{S}$. in the request of $\mathrm{V}$. refused, arguing that there are no grounds for termination of the case. In order to avoid making a decision that K. would be found guilty, B. purchased weapons for committing the murder. In the evening V. approached the house of S., aimed toward the window and fired a shot in the figure that appeared in the window. Later it was discovered that B. killed his brother S.

Take a look at the article. Art. 115, 379, 368 of the Criminal Code. Identify the objects of criminal encroachment committed by $\mathrm{V}$.

Case 4

Employees of the SBU at the time of departure were arrested by G. and P., who tried smuggling out more than 50 icons from Ukraine, which have historical and cultural value. 
Take a look at the article. $201 \mathrm{KK}$. Determine the object and object of the crime committed by G. and P.

\section{Case 5}

D. acquired from the unidentified person imitation fires for training simulation grenades and pyropatrones and illegally stored them in his apartment. Judgment D. was convicted under Part 1 of Art. 263 of the Criminal Code.

Can objects be marked with the objects of the crime envisaged in Art. 263 of the Criminal Code of Ukraine?

Read the resolution of the Plenary Session of the Supreme Court of Ukraine "On Judicial Practice in the Case of Abduction and Other Illicit Handling of Weapons, Ammunition, Explosives, Explosives or Radioactive Materials" of April 26, 2002 No. 3.

\section{Case 6}

Leading one of TV programs, S., conducting a journalistic investigation, discovered how he seemed to be the leaders of the organization that carried out the illicit trade in firearms. A few days after the announcement of this fact on television, S. found in his office a note threatening his life and the life of his loved ones. After some time, unknown persons closed the cage in his own car and began to beat the car with metal bars, disarming him.

Take a look at the article. Art. 129, 171, 194 of the Criminal Code. Identify the object, subject, and means of this crime.

\section{Theme 7: The objective side of the crime}

1. The notion of the objective side of the crime and its significance for qualification. Signs of the objective side of the crime. Features of the design of the objective side in the formal and truncated crimes.

2. The concept and form of the act. Approaches to the definition of action and inactivity in legal literature. Criminal liability for inactivity.

3. The concept of socially-dangerous consequences and their classification in legal literature.

4. Causal connection as a sign of the objective side of the crime in the material composition of crime, its concept and meaning in the criminal law of Ukraine.

5. Theories of cause and effect communication in criminal-law doctrine and their practical application. 
6. Optional signs of the objective side of the crime and their significance for the proper qualification of crimes in the competition of criminal law.

\section{Task:}

1. In writing, separate the concepts of material, formal and truncated crimes. Give examples.

2. Find the Criminal Code of Ukraine and write 4 examples of rules that provide for liability only for inaction.

3. Write down the synopsis of the theory of causation and briefly define their general provisions.

4. Write in the abstract from the Criminal Code on 3 examples of criminal law, in which the facultative signs of the objective side of the crime become meaningful:

a) mandatory signs of the crime;

b) qualifying signs of a crime;

c) circumstances that aggravate or mitigate the punishment.

Case 1

Returning from his studies, A saw near a tram stop of a man who, being drunk, froze while sitting under a tree (the temperature of that day reached -20 degrees Celsius). Having approached the man A. asked him why he did not go, but did not get an understandable answer. After that, A. went further, and her husband remained freezing in the same place. On the question of law enforcement officers, A. later explained that there were many people at the tram stop who were also able to provide assistance, so he did not consider himself obliged to do so.

How can the qualified actions of $A$. be in the case of death of this person as a result of abandonment without help?

\section{Case 2}

P. and C., resting on the banks of the river, argued, which of them will soon cross the river. Somewhere in the middle of the river, S. understood that the plates could no longer be, because his legs were erected by convulsion. He began to call P. to help. However, the latter, without paying attention to the calls for help, floated on the opposite side. S. after a few calls drowned. P. explained the reluctance of fear to drown with $\mathrm{C}$ and confusion at the time of the event.

Does the inactivity of $\mathrm{P}$. constitute the objective part of the crime provided for in art. $135 \mathrm{CC}$ ? Is it possible to consider that participation in a dispute determines actions that pose a danger to other persons (in this case, does it mean, has P. put its actions 
in a position that is dangerous to life)? Does the degree of risk for P. life, which would have taken place in the event of salvation, is important?

Case 3

S., being in a state of intoxication, broke the glass and penetrated into the apartment of M. Zavolodshivsya property in the amount of $7000 \mathrm{UAH}$., Fled from the place of the crime, but initially opened water taps from the hooligan motives and caused the flood of the apartment of M. and its neighbors .

Take a look at the article. 185 of the Criminal Code. Specify the proper signs of the objective side and their significance for qualifying actions.

Case 4

The emergency aid team of the district hospital received three calls from the villages of the district at the same time. Doctor I. decided to first go to the most remote village, and then, going back, drove to the others. On the way, the driver had to repair a sanitary car, there was a delay. When the brigade arrived in the second patient after 2 hours, it was already dead. Forensic medical examination has established that life of the patient could be saved in case of timely medical assistance.

Is there a causal link between the actions of physicians and the onset of a patient's death?

Case 5

I., having gone to the restaurant, saw P., who danced with his friend. I. was in hostile relations with P. Having grabbed a pistol, I. from a distance of 7 meters shot three times in P., causing deathly injuries. By a court judgment, the actions of $\mathrm{I}$. were qualified under Clause 5, Part 2, Article. 115 CC.

Has the court actually come to the legal assessment of the way the crime was committed?

Case 6

On the day of the election of Mayor G., knowing that his parents would vote for a representative of the opposition forces, locked them in an apartment on the 7th floor, previously turned off the phone, and he himself went to the polls. He returned home at 11 o'clock that same day.

What exactly is the legal meaning of the time of committing a crime for the qualification of an act under art. 157 of the 
Criminal Code of Ukraine? Does the method of committing such an act matter?

\section{Theme 8. The subject of the crime}

1. Concept, signs of the subject of a crime.

2. The value of the subject of the crime.

3 . The concept and criteria of sanity and insanity.

4. Concept and legal consequences of limited sanity.

5. Concept and types of age of criminal responsibility.

6 . The moment of reaching a certain age, its significance for recognizing a person as guilty of committing a crime. Appointment of forensic examination for age determination.

7. Concept and types of signs of a special subject of a crime.

8. Criminal liability for crimes committed in a state of intoxication: types of intoxication, their influence on the person's responsibility.

\section{Task:}

1. Make a note of the "insanity" of the person and write down in the notebook.

2. Write in the abstract 4 examples of the rules of the $\mathrm{CC}$, where the subject is general.

3. Divide the notion of the subject of the crime and the offender.

4. Write in the notebook 5 criminal law provisions that provide for criminal liability of 16 years.

5 . Write in the notebook 5 criminal law provisions that provide for criminal liability of 14 years.

6. Write in the abstract 3 criminal law that indicates the increased age of criminal responsibility.

7. Write in the abstract 4 examples of the rules of the $\mathrm{CC}$, where the subject is special.

Case 1

S. was in a hostile relationship with $\mathrm{A}$. and therefore hunted a dog on him. As a result of the attack of the dog A., he received moderate bodily injuries.

Identify the subject of the crime.

Case 2

V., who systematically leaked for 10 years and insulted his wife, once again came home drunk. As always, he began to offend her, hit his head. Due to the systematic abuse of a man in his wife, a state of intense emotional excitement arose and she 
struck him in the chest with a knife, which at that moment was cucumber clean. The heart damaged the knife, the man died. His wife V. was sentenced for intentional murder, committed in a state of intense emotional excitement. The lawyer appealed the verdict, believing that the crime was committed in a state of insanity.

Is the complaint subject to satisfaction?

Case 3

For murder, when exceeding the limits of the necessary defense, B. was sentenced to 1 year of corrective labor. Before the entry into force of the verdict, B. was ill with a mental illness, which deprived him of the possibility of realizing his actions, and was directed to treatment. After 2 years he was cured.

Should B. serve a sentence imposed by a court sentence?

Case 4

M., who was in a state of dignity, committed the sabotage provided for in art. 113 of the Criminal Code of Ukraine, but after that he became ill with dementia.

How to solve the question of M. responsibility?

Case 5

Adolescent K., together with E., who was not 14 years old, committed three thefts of someone else's property. Actions K. court qualified for Part 2 of Art. 185 of the Criminal Code as a theft committed by a group of persons at the prior conspiracy.

Is the issue resolved correctly?

Case 6

On the day of his 14th anniversary, September 3, 2004, at about 22 hours 45 minutes, he murdered.

Is $\mathrm{G}$. subject to criminal liability?

Case 7

The 15-year-old K's got to the cabin of someone else's car and decided to ride there. When driving, he did not see a warning sign about a steep turn and drove into a concrete pillar. The car was broken, and $\mathrm{K}$. received fractures.

What should be the criminal-law assessment of the actions of K.? Take a look at the article. Art. 194, 196, 289 of the Criminal Code.

Option 1: K. made an accident, during which three people were seriously injured.

Option 2: K. was traumatized by a single citizen. 
Take a look at the article. st.119, 121, 286 of the Criminal Code.

Case 8

Sh., 14 years old, repeatedly committed pocket thefts in urban transport. During the new theft, he was detained by police officers. On his excuse, he stated that he was not 16 years old, so he was not responsible for the crime.

From what age is a person subject to criminal liability for theft (Article 185 of the Criminal Code)?

Case 9

K. On May 23, 2004, at 23 hours 50 minutes, he hijacked the river vessel (Part 1 of Article 278 of the Criminal Code of Ukraine), and on May 24, 2004, he was 14 years old.

Does K. Criminally liable?

Case 10

The 15-year-old pupils of $\mathrm{H}$. and $\mathrm{L}$. decided to take classes at school and call the police that the school was mined. Classes in school were canceled. The miners spent several hours examining all the premises of the school, but no explosives were found.

Take a look at the article. Art. 259, 296 of the Criminal Code. Can $\mathrm{X}$ and $\mathrm{L}$. be responsible for the actions taken under these articles of the Criminal Code?

Option: May 12, L. celebrated its 16th anniversary and made the following message at 00 hours 30 minutes.

\section{Topic 9. The subjective matters of the crime} crime.

1. The concept and meaning of the subjective part of the

2. The main and additional features that characterize the subjective aspect of the crime.

3. The concept and forms of guilt.

4. Concept and types of intent.

5. Concept and types of careless form of guilt.

6. Casualty, its distinction from criminal negligence.

7. Mixed (double, complex) guilt.

8. The concept and meaning of the motive of the crime.

9. The concept and meaning of the purpose of the crime.

10. General characteristics of emotions and emotional states.

11. The concept of legal error and its legal meaning.

12. Concept and types of actual error, its meaning. 
Task:

1. Fill in and write down to the outline the scheme of intellectual and volitional moments of direct intent.

2. Make up and write down to the summary a diagram of the intellectual and volitional moments of indirect intent.

3. Write down to the abstract 4 examples of criminal law that contain an indication of intent, indicate its form

4. Make up and write down a schematic diagram of the differences between the implied intent and the criminal selfconfidence.

5. Fill in and write down the schematic diagram of the intellectual and voluntary elements of criminal negligence.

6. Write down to the abstract 5 examples of criminal law, which include an indication of the careless form of guilt, indicate the kind of carelessness.

7. Write down to the summary 5 examples of criminal law that contain mixed blame.

8. Write in the abstract 3 examples of criminal law that contain an indication of the motive of the crime.

9. Write in the abstract 3 examples of criminal law that contain an indication of the purpose of the crime.

10. Write down to the summary 3 examples of criminal law that contain an indication of the emotional state.

\section{Case 1}

While on disco, Z. quarreled with S. and P. unfamiliar to him earlier. After the disco, S. and P. drove $Z$. to the courtyard of the house and beat him violently, striking several strikes with armature bars on the head. As a result of injuries, Z . died.

Take a look at the article. Art. 115, 121 of the Criminal Code. Identify the form and type of guilt that the guilty guy acted on.

Case 2

N. and P., while in the apartment of N., used alcoholic beverages. When the drinks were over, N. began to demand from P. to go for an additional portion. To refuse P. N. responded to beatings in the area of the head, neck, and chest. He stopped only when the phone rang. As a result of injuries, P. died.

Take a look at the article. Article 121 of the Criminal Code. Solve the question of the subjective matter of the crime. 


\section{Case 3}

S. decided to kill R., ran behind him to the bank where there were another 14 people, and threw a grenade. As a result of his actions, 5 people died, 7 were injured.

Take a look at the article. Art. 115, 121 of the Criminal Code. Solve the question of the subjective aspect of the crime.

Case 4

G., who worked as a cleaner in kindergarten, having finished work and going home, forgot to exclude an electric cooking hob, resulting in a kindergarten house burned down.

Take a look at the article. 196 CK. Determine type of guilt.

Case 5

S., driving a car, moved through the streets of the city with excess speed, relying on the fact that, if necessary, he, as a driver with 16 years of experience, will have time to slow down. He did not manage to manage and made a ride on $Z$.

Take a look at the article. 286 of the Criminal Code. Determine the shape and type of guilt.

Case 6

G., who worked as a swimming trainer in the "Olympian" pool, gave a group of beginners - students of the junior class - a task and traced how they with special boards in their hands descended to the pool. Then she violated the established rules of training novices approached a colleague on the job, releasing from the field of view his group. Suddenly there were loud cries of children who were calling for help. Having rushed into the water, one of the coaches lifted a girl from group G. from the bottom of the pool. After giving first aid, the child was immediately brought to the hospital's intensive care unit. However, it failed to save it.

Should she be responsible for the girl's death? Take a look at the article. 137 of the Criminal Code.

Case 7

M.M celebrated her birthday bying in a shop 3 bottles of champagne. On the holiday champagne was first tested by M's son., and then he died.

Does MM have criminal liability? 
Case 8

B. from the hooligan's motives hit Sh. In the face. Sh. fell from the blow and hit his head against the curtain. Sh. Died of a trauma in the hospital.

Take a look at the article. Art. 115, 119, 121, 122, 125 of the Criminal Code. Solve the question of the subjective aspect of the crime.

\section{Case 9}

$\mathrm{BC}$ came to brother. He, as always, was drunk and, as always, demanded money for alcohol and threatened with physical harassment. While cooking dinner in the kitchen, B. listened to his drunken threats silently, without turning around. When suddenly he felt his approaching, he turned instinctively sharply, holding the kitchen knife. Brother caught on his chest and fell to the floor. B. immediately called for ambulance, but before her arrival from the wounded heart, her brother died.

Does B. have to be responsible for the death of his brother?

\section{Topic 10. Stages of intentional crime}

1. The concept and types of stages of the commission of a crime.

2. Preparing for a crime, its characteristics. The delineation of preparation for crime from the manifestation of intent.

3. Concept and types of attempted crime.

4. Finished crime. Features of the end of individual syllables of crimes.

5. Grounds and limits of criminal liability for previous criminal activity.

6. Voluntary refusal to bring the crime to the end.

7. Difference of voluntary refusal of effective repentance.

Task:

1. Write down a summary of the rules for the qualification of an unfinished crime.

2. Determine the moment of the end of certain types of crimes.

Case 1

P. was detained by a police officer D. while selling two bags of poppy straw to a drug addict. She offered D. to leave her $\$ 170$ withdrawn from her, the protocol did not compile and release her, promising to transfer another $\$ 200$ to the next day. D. refused and informed about the actions of $P$. to the prosecutor's office. 
How should this matter be resolved? Take a look at the article. Art. 368, 369 of the Criminal Code.

\section{Case 2}

In order to get rid of his wife and daughter, G. made an explosive device with a clock mechanism, put it in a suitcase with the products that they took with them to Moscow for relatives, and handed along with other things to the cargo compartment of the aircraft, which his wife and daughter had to fly from Kiev to relatives. On board the aircraft there were 168 passengers and 8 crew members. The device had to work at a time when the airplane would be in the air. However, because at the airport the loaders carefully threw things, an explosive device had an electrical contact and it did not work.

Take a look at the article. $115 \mathrm{CK}$. What is the stage of committing a crime in the actions of G.?

\section{Case 3}

In order to take possession of money P., R. and K. decided to poison her. They purchased a poison that was intended to destroy rodents, and $\mathrm{K}$. gave it to P., under the guise of drugs for gastric disease. A nausea began to $\mathrm{P}$, no other consequences were been. The examination found that the powder was not suitable for human poisoning.

Are R. and K. subject to criminal liability?

Case 4

T., a non-official employee of the meat-packing plant, during his duty to hide a cart in an auxiliary room, which had five sacks with by-products. The next day he suggested that D. and M. take part in the theft. The latter agreed. All three picked up the cart to the fence, threw bags over it and began to load on the car, but were detained by police officers.

At what stage was the crime interrupted? Are T., D., and M. subject to criminal liability?

Case 5

P., having decided to kill $\mathrm{F}$., waited for her roadside along the abandoned construction. Having seen F., P. from a hunting gun did 2 shots in her, but did not hit. He did not shoot more and refused his criminal intentions.

How should the actions of $P$. be viewed from the point of view of the doctrine of the stage of the commission of a crime? 


\section{Case 6}

Having come to the house of his former wife, K. threatened her with extortion, and then grabbed a knife and hit the head with a handle, causing light bodily injuries with a short-term health disorder. After suffering, he ran into another room, K. caught her, dumped on the floor and began to choke, asking, "Will you live with me, or will I kill?" The cry began to crash, asked not to kill her, because the children will remain orphans. K. stopped his actions and with the words "What I did ..." came out of the room.

Take a look at the article. Art. 115, 125 of the Criminal Code. At what stage has the crime been interrupted? Is there a voluntary refusal to commit a crime in the actions of K.?

\section{Case 7}

During a quarrel with his wife K., on the ground of jealousy, she struck her with a knife in the heart, causing severe bodily harm. Frightened the accomplice, he pressed the wound with a towel and began to call for help. The neighbors who rushed to the apartment, at his request, called for ambulance. The survivor's life was saved.

Is there a voluntary refusal to commit a crime in the actions of K.?

\section{Case 8}

An employee of the private enterprise L., having learned that in the accounting safe of the enterprise there is located a significant amount of money, decided to steal them. Breaking the glass in the window, he penetrated into the room and tried to break the lock of the safe. But he managed to only bend the left corner of the upper part of the doors. Realizing that it would not be possible to open the safe deposit box, L. went home.

Is L. responsible for criminal liability?

\section{Case 9}

B. during a quarrel with $\mathrm{K}$. tried to strike his blade with an ax on his head, but the latter closed his head with his hand and the blow came to her. With repeated attempts to strike, he rejected his head and hit the right forearm. Then V. picked up the victim and took him to the house. K. was seriously injured.

What should be the criminal-law assessment of the actions of V.? 


\section{Topic 11. Participation in the commission of a crime}

1. Concept and meaning of complicity.

2. Objective and subjective signs of complicity.

3. Theories of complicity in criminal law.

4. Types of accomplices, grounds and limits of responsibility.

5 . Features of voluntary failure of accomplices.

6. Forms of complicity.

7. The concept and separation of a group of persons without prior conspiracy and a group of persons by prior agreement.

8. The notion and distinction between an organized group and a criminal organization.

9. Participation in crimes with a special subject.

10. Excess.

11. Responsibility for unsuccessful incitement and aiding and abetting.

12. The question of complicity in careless crimes.

13. Concept and types of involvement in a crime.

14. Criminal liability for concealing a crime.

15. Features of responsibility for condemning a crime and not reporting about a crime.

\section{Task:}

1. Record the objective and subjective signs of complicity.

2. Separate in the notebook the signs of a group of persons by prior agreement, an organized group and a criminal organization.

3. Write in the note the basic provisions of the theories of complicity in criminal law.

4. In the summary in a note, justify the difference in the involvement in the crime of complicity in the crime.

Case 1

E. encouraged the minor $\mathrm{K}$. and the minor $\mathrm{S}$. to commit a number of thefts from citizens' apartments on other floors of buildings. At the same time, K. or S. slept in the apartments through the window of the window and handed over the stolen things to $\mathrm{E}$.

Is there any complicity in the actions of $\mathrm{Y}$.

Case 2

A. lived together with his son $\mathrm{N}$. and his wife. She had a hostile relationship with the daughter-in-law, and she tried to create for the unbearable conditions: refused to eat, forced to perform hard work, forbade to communicate with her neighbors, offended her and every day complained about her son. Therefore, 
N. often quarreled with his wife, beat her, and after another quarrel shot with a pistol.

Can A. be recognized as an instigator before the murder?

Case 3

An employee of the exploration party S. during the hunt noticed at dawn that something shifted in the bushes near the village and saw some kind of black shadow in the fog against the background of greenery. Thinking that the bear was, S. ran into the house, awakened B. and reported it. Both of them took the guns and, having crawled to the shore of the river, made shots in the bush, where it was heard the crack of branches. A bullet from the rifle S. was killed by V., who was there. Bullet from the rifle $B$. did not hurt the latter.

Is there a complicity in the crime of $\mathrm{S}$. and B.?

Case 4

L., working at the railway station, knew that on the alternate route there was a storage of batteries, and a few cars of this warehouse were not sealed. In carrying out his duties, he, passing along with this warehouse, noted that the employee of the same station $\mathrm{K}$. from one car makes two batteries. Having decided to take advantage of the situation, L. also got into this car and stole the batteries, when he tried to sell one of them he was detained by law enforcement agencies.

Can L. and K. recognize adherents of the crime?

\section{Case 5}

$\mathrm{G}$ in the company of his comrades spoke about the fact that his friend, a well-known collector of antiques, L., in the apartment, among other things, has paintings of great value. At the same time, he expressed extreme surprise that L., leaving for frequent business trips, left the painting virtually without any protection. M., one of the comrades G., taking advantage of the information of G., found out the address of L., secretly penetrated into the apartment of the latter and stole three paintings. G. was charged with incitement to theft.

How justified is the allegations?

Case 6

L.V., quarreled with G. and his friends, told about his brother L.Yu. and with him returned to the place of adventure. L.Yu. took with him a knife, about which L.V. did not know. Approaching the guys sitting on the bench, L.Yu. hit one of them - I. The fight 
started. L.Yu. twice hit G. with a knife in his chest, and then injured Z. L.V. At that time, he struck the wounded doctor with his fists. From the knife injuries he received, he died at the hospital.

Is there any action of L.V. and L.Yu. complicity? If so, which form?

\section{Case 7}

To L., who repaired his own car, came three teenagers and asked if he would buy them at their price, twice as low as the retail, wheels for the car. L. agreed. Teenagers in the next street at night removed four wheels from the car O., and the next day they brought them L., having received a specified amount of money.

What should be the criminal-law assessment of the actions of L. and adolescents?

\section{Case 8}

There was a quarrel at the dispatching garage between L. and $\mathrm{S}$. in the presence of $\mathrm{M}$. during which they insulted each other. She struck L. with his fist. L. grabbed a metal band $1.5 \mathrm{~kg}$ in weight and struck her with a shock, causing a fracture of the collarbone. M., who saw all this, and who dreamed of revenge for the insult he had inflicted on him a month ago, tore out L. Blob's hand and struck him on the head, causing a fracture of the skull.

Is there a complicity in the crime in this situation?

Case 9

Ch., in a state of intoxication, came to the apartment to the students of technical college - juveniles P., B. and V. - and proposed to steal from the premises of the college two computers and TV, on which they gave consent. Ch. was standing guard at the entrance to the building, and V., B. and P. entered the technical school, made two computers and a TV set costing \$ 1,600 in suitcases, as well as a color photocopying machine, a color printer and a scanner costing $\$ 3,000$, but when leaving the premises, they were detained by police officers.

Is there a complicity in this case?

Case 10

Being drunk, A. and V. decided to "instruct" the policeman P., who once detained them for violations of public order. Having met him on the street, they began to beat him, and when he fell, 
A. grabbed a knife from his pocket and hit P. After the injury, the latter died. It was established that A. A. gave V. "just in case" a few minutes before the meeting with P. He himself struck the victim several times with his hand.

Is there an excess of performer in the actions of $\mathrm{A}$.

Case 11

I asked the driver of the car at the fuel depot I. to steal at the base and bring him a barrel of gasoline for his reward, and when he, at the previous conspiracy with the watchman of the petrol station, did this, Ya paid I. and P. 300 hryvnias. The local court convicted Ya.under Part 4 of Art. 27, part 2 of Art. 185 of the Criminal Code of Ukraine. In the appeal, Ya. asked to change the qualification of his actions, since he committed theft to I. only, but that he had committed theft under the previous conspiracy with P., he learned only when I. with P. brought the kidnapped gasoline to him home.

What decision is to be taken by the Court of Appeal?

Case 12

The senior investigator of the prosecutor's office B. investigated the case of rape by a group of teenagers. The parents of the suspects agreed to give one another an unjustified benefit for terminating the criminal proceedings. To this end, they appealed to the Chief Legal Officer $D$. with a request for remuneration to arrange with $\mathrm{B}$. She passed the proposal of B. parents, and he agreed to take a decision to stop the criminal proceedings for a bribe. Having received from his parents \$5,000, D \$ 700 was transferred to B., and the rest was donated.

How should you solve the case?

Case 13

$\mathrm{K}$. and Sh. agreed in advance to commit theft of property from $B$ apartment. Knowing that B. with his family on the weekend leaves for the country, they on Saturday night with the help of switches entered the apartment. Not including the light, in order not to attract the attention of neighbors, began to look for valuable things. Entering one of the rooms, $\mathrm{K}$. found the old one who woke up, which later turned out to be the father of B. and did not go to the country because of what he was feeling badly. The old man, frightened, began to call for help. K. grabbed a metal ashtray, caught in his hand, hit her old in the temple. The 
victim died in a few minutes. When he ran to Sh., K. ordered to go and told about what had happened. Having captured some more things, the criminals were hiding. Stolen property is divided among themselves.

Define the form of complicity in this crime. Who should be held liable for the willful murder of a person?

\section{Case 14}

On July 9, V. informed U. about his robbery and the murder of $\mathrm{P}$. and asked to take possession of some of the things stolen by him. On the same day, V. was arrested, and on July 10, the investigating authority found that he was the murderer. $U$. at interrogations about B. made him confession and transfer to storage of stolen things the investigator did not report.

Read article 198, 396 of the Criminal Code. How to deal with U. action?

\section{Case 15}

The "thief in law" N. with the "proposal" to prepare and provide a meeting of representatives of criminal organizations, criminal authorities and "thieves in the law" turned to the director of the boarding house H. H. was afraid to refuse N., knowing its "cool" character. The meeting was held.

Is $\mathrm{X}$. subject to criminal liability and under what article of the Criminal Code? Take a look at the article. Art. 255 and 256 of the Criminal Code of Ukraine.

\section{Case 16}

K., who stole property values from the apartments, took them to storage for his acquaintance. VV knew that the property was stolen, took it for storage and realization.

M., cousin B., also knew that his relative kept and sells someone else's property stolen from citizens, but the authorities did not make a statement of this kind.

From the position of the doctrine of complicity, analyze the actions of each of these individuals.

\section{Topic 12. Multiple crime}

1. The concept of a single crime. Types of single crimes.

2. Concept, features and types of ongoing crimes.

3. Continued crime.

4. Committed crime.

5. An offense with derivative effects. 
crimes.

6. The concept of plurality of crimes. Signs of plurality of

7. Value multiplicity of crimes and single crimes.

8. General characteristics of forms of plurality of crimes.

9. Legal implications of the plurality of crimes.

10. Concept, types and qualifications of repetition of crimes.

11. The concept, types and qualifications of the totality of crimes.

12. The concept, types and qualifications of the relapse of crimes.

13. Combination of several forms of plurality of crimes.

Case 1

There was a controversy in the room of the dispatching garage between P., S., and T. When $\mathrm{SH}$ and $\mathrm{T}$ started to beat P., the latter grabbed a metal blanket and, with the aim of killing both, hit him with a blow to the head, and when he fell, he hit twice on the head of T. From the injuries he received, he died on the spot. events

How many crimes did P.?

Case 2

R., being drunk, knocked out the door of the grocery kiosk, walked in and took five bottles of vodka, three bottles of cognac, thirty chocolate bars and eight boxes of candies. He took all this to his home.

After drinking half a glass of cognac at home, $\mathrm{R}$. decided to return to the kiosk. R. returned to the kiosk, went in, but K. was noticed and detained. During the interrogation, R. explained that he returned to the kiosk, because at home he had the intention of taking away from the kiosk the rest of the bottles of vodka and cognac that remained there.

Is it possible to judge the actions of $\mathrm{R}$. as a single crime?

Option: During interrogation $\mathrm{R}$. explained that the intention to take all the bottles of vodka and brandy came from him before penetrating the kiosk, but he decided to implement this intention in two ways.

\section{Case 3}

P. met at the beach with $G$. and invited her to go home to watch video films. After viewing them, he suggested that G. stay at him for the night, and when he refused, he closed the door and, threatening the knife, several times entered into her sexual 
intercourse. In the morning P. took G. to the apartment where she lived.

How many crimes did P.?

Read the resolution of the Plenum of the Supreme Court of Ukraine No. 5 dated May 30, 2008 "On judicial practice in cases of crimes against sexual freedom and sexual integrity of a person".

\section{Case 4}

K., having become a person without a certain place of residence, has decided to obtain his means of living through the abduction of foreign property from citizens at stations and ports. January 19 at the Kyiv-based station stole a backpack with personal belongings in Moscow; July 27 stole a suitcase in T. in the sea port of Illichivsk. In total, in this way, he committed eight thefts in the territory of Ukraine for a total amount of UAH 3,500.

Is it possible for $\mathrm{K}$. deed to be qualified as a single offense?

Case 5

During the execution of the sentence for robbery, A. and P. agreed that when the latter comes to power, they will get and give narcotic drugs to the colony. Three weeks after his release, P. bought from the unidentified person $2.5 \mathrm{~kg}$ of annas, brought her to the city where A. mother lived, and left her. She had a few months to keep her at home, and then handed her to her son during another appointment. When trying to sell an an ana to another convict, A. was detained.

Did the plurality of crimes happen in this case?

\section{Case 6}

K., working as a taxi driver, raped a citizen of the car in a car. The next day, he reported the incident to the police, and in a few days it became clear that $K$. infected her with venereal disease, as reported by the investigator.

Do the actions of $\mathrm{K}$. constitute the plurality of crimes?

Case 7

B., previously sentenced to robbery, after the imposition of a punishment, organized a group for committing apartment thefts, which previously had not been convicted of P. and C. They developed a single plan for theft, distributed among themselves functions, identified the first two apartments, from which they will begin activity. 
At first they stole the apartment of R., causing him a property damage amounting to 210,641 hryvnias, then penetrated into the apartment of G., put in two bags his property for the amount of 310,869 hryvnias, but when the bags were taken out of the apartment were noticed by a neighbor who made a hurry. Despite this, B., P. and C. fled with bags down, drove into a car belonging to $\mathrm{P}$., and fled.

What forms of plurality of crimes took place? What is their criminal significance?

Option: Neighbor, making noise, blocked the road to the stairs. Then B., without throwing the bags, pushed her to P. and S., and they struck her head against the wall, causing her to be injured with moderate gravity. 


\section{USED SOURCES}

1. Andrew Ashworth. Principles of criminal law - Oxford univ. press, 5-th edition, 2007. - 508 p.

2. Joshua Dressler. Black Letter Outline on Criminal Law. West academic publishing, $2^{\text {nd }}$ edition, 2010. $-448 \mathrm{p}$.

3. Encyclopedia of Crime and Justice / J. Dressler, ed. in chief. - Macmillan reference USA, $2^{\text {nd }}$ ed, 2002. - Vol. 1. - 498 p.

4. Dr. Thomas O'Connor. Web Syllabus on Criminal Law (http://www.drtomoconnor.com/3010/default.htm)

5. Allen, M. Textbook on Criminal Law (8th ed., Oxford: Oxford University Press, 2005).

6. Battistella, E. Linguistic Aspects of Legislative Expression by Frederick Bowers (A review). Language, Vol. 67, No. 2 (Jun., 1991). - Pp. 390-391.

7. Dressler, J. Understanding Criminal Law, (2nd ed., 1995).

8. Fish, S. There's No Such Thing as Free Speech ... and It's a Good Thing, Too. (New York: Oxford UP, 1993).

9. Fletcher, G.P., Rethinking Criminal Law (1978).

10. Hall, J., General Principles of Criminal Law (2nd ed., 1960).

11. Jefferson, M. Criminal law (7th ed., London: Longman, 2005).

12. Nerhot, P. Law, Writing, Meaning: An Essay in Legal Hermeneutics. (Edinburgh: Edinburgh Press, 1993).

13. Ormerod, D. Smith and Hogan Criminal law (11th ed., Oxford: Oxford University Press, 2005).

14. Politics, Postmodernity and Critical Legal Studies: The Legality of The Contingent. Edited by Costas Douzinas, Peter Goodrich, \& Yifat Hachamovitch. (London: Routledge, 1994).

15. Robinson, P.H. Fundamentals of Criminal Law ( 2nd ed., 1995).

16. Samaha, J. Criminal Law. (6th ed., West Publishing Company, 1984).

17. Solan, L.M. The Language Of Judges (Chicago: U. of Chicago Press, 1993).

18. Substantive criminal law of England and Wales // Criminal Law Forum - Volume 17, Number 1 / 2006.

19. Warnke, G. Justice and Interpretation (Cambridge: MIT Press, 1993). 
20. White, J. B. Acts of Hope: Creating Authority in Literature, Law, And Politics. (Chicago: U. of Chicago Press, 1994).

21. White, J.B. Justice as Translation: An Essay in Cultural and Legal Criticism. (Chicago: U. of Chicago Press, 1990). 
Izdevniecība "Baltija Publishing"

Valdeksu iela 62 - 156, Rīga, LV-1058 www.baltijapublishing.lv

Iespiests tipogrāfijā SIA "Izdevniecība "Baltija Publishing"

Parakstîts iespiešanai: 2017. gada 28. septembris Tirāža 150 eks. 